NUREG/CR-6528

\title{
Environmental Assessment Proposed License Renewal of \\ Nuclear Metals, Inc. Concord, Massachusetts
}

Manuscript Completed: February 1997

Date Published: February 1997

Prepared by

Miller, R. L., Easterly, C. E., Lombardi, D. A., Treitler, I. E., Winbow, R. T., Zimmerman, G. P.

Oak Ridge National Laboratory

Managed by Lockheed Martin Energy Research Corp.

Oak Ridge, TN 37831-6370

Prepared for

Division of Industrial and Medical Nuclear Safety

Office of Nuclear Material Safety and Safeguards

U.S. Nuclear Regulatory Commission

Washington, DC 20555-0001

NRC Job Code J5084 



\begin{abstract}
The U.S. Nuclear Regulatory Commission (NRC) has prepared this Environmental Assessment (EA) to evaluate environmental issues associated with the renewal of licenses issued by NRC for facilities operated by Nuclear Metals, Inc. (NMI) in Concord, Massachusetts. By renewing the licenses, NRC proposes to allow the continuation of ongoing operations involving radioactive materials at NMI's facilities. This EA focuses on the potential impacts related to air emissions at NMI during normal (incident-free) operations and accidental releases. Findings indicate that there are only two areas of potential concern. First, modeling results for sulfur dioxide $\left(\mathrm{SO}_{2}\right)$ emissions from the boilers during normal operations indicate that the potential exists for exceeding the short-term National Ambient Air Quality Standards (NAAQS). NMI is prepared to undertake mitigative action to prevent potential exceedances of the short-term $\mathrm{SO}_{2} \mathrm{NAAQS}$, and the Massachusetts Department of Environmental Protection is prepared to resolve the issue via a permit/approval change or through a Consent Order. Second, in the unlikely event of a severe fire, predicted sulfuric acid $\left(\mathrm{H}_{2} \mathrm{SO}_{4}\right)$ concentrations based on conservative (upper bound) modeling exceed the Emergency Response Planning Guideline (ERPG) levels. NMI has committed to NRC to give a briefing for local emergency response officials regarding the potential for an accidental $\mathrm{H}_{2} \mathrm{SO}_{4}$ release.
\end{abstract}





\section{DISCLAMMER}

Portions of this document may be illegible in electronic image products. Images are produced from the best available original document. 


\section{DISCLAIMER}

This report was prepared as an account of work sponsored by an agency of the United States Government. Neither the United States Government nor any agency thereof, nor any of their employees, make any warranty, express or implied, or assumes any legal liability or responsibility for the accuracy, completeness, or usefulness of any information, apparatus, product, or process disclosed, or represents that its use would not infringe privately owned rights. Reference herein to any specific commercial product, process, or service by trade name, trademark, manufacture, or otherwise does not necessarily constitute or imply its endorsement, recommendation, or favoring by the United States Government or any agency thereof. The views and opinions of authors expressed herein do not necessarily state or reflect those of the United States Government or any agency thereof. 
TABLE OF CONTENTS

ABSTRACT $\ldots \ldots \ldots \ldots \ldots \ldots \ldots \ldots \ldots \ldots \ldots \ldots \ldots \ldots \ldots \ldots \ldots \ldots \ldots \ldots$

ACRONYMS AND ABBREVIATIONS $\ldots \ldots \ldots \ldots \ldots \ldots \ldots \ldots \ldots$

EXECUTIVE SUMMARY $\ldots \ldots \ldots \ldots \ldots \ldots \ldots \ldots \ldots \ldots \ldots \ldots$

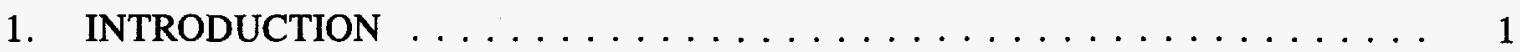

1.1 PURPOSE OF AND NEED FOR THE PROPOSED ACTION . . . . . . . . . 1

1.2 BACKGROUND INFORMATION ON NUCLEAR METALS, INC . . . . . . 2

1.3 SCOPE OF THE ENVIRONMENTAL ASSESSMENT $\ldots \ldots \ldots \ldots \ldots$

2. THE PROPOSED ACTION AND ALTERNATIVES $\ldots \ldots \ldots \ldots \ldots \ldots$

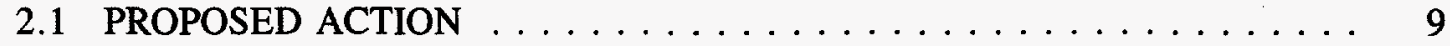

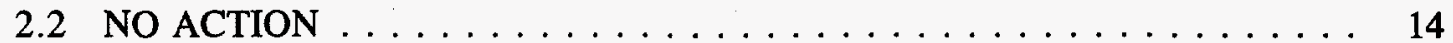

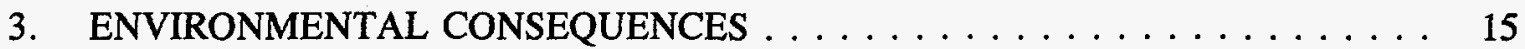

3.1 ENVIRONMENTAL CONSEQUENCES OF THE PROPOSED ACTION . . 15

3.1.1 Incident-free Atmospheric Releases . . . . . . . . . . . . . . . 15

3.1.1.1 Climatology and air quality . . . . . . . . . . . . . . . . . . . . . . . . . .

3.1.1.2 Radiological impacts . . . . . . . . . . . . . . . . . . 19

3.1.1.3 Nonradiological impacts ................ 23

3.1 .2 Accidental Atmospheric Releases . . . . . . . . . . . . 28

3.1.2.1 Uranium inventories . . . . . . . . . . . . . . 28

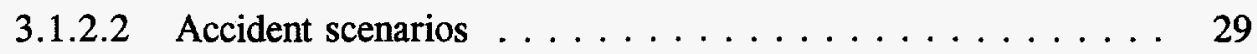

3.1.2.3 Fire-related assumptions .............. 31

3.1.2.4 Accident analysis . . . . . . . . . . . . . 32

3.1.2.5 Radiological impacts of uranium . . . . . . . . . 38

3.1.2.6 Chemical toxicity of uranium ... . . . . . . . . . . 41

3.1.2.7 Nonradiological materials . . . . . . . . . . . . . 42

3.1.3 Environmental Justice . . . . . . . . . . . . . . . . . . 48

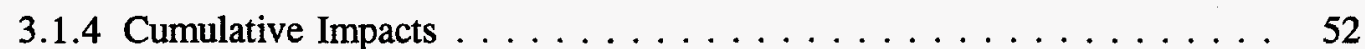

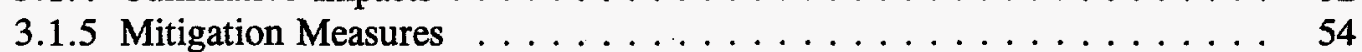

3.2 ENVIRONMENTAL CONSEQUENCES OF NO ACTION $\ldots \ldots \ldots \ldots .54$

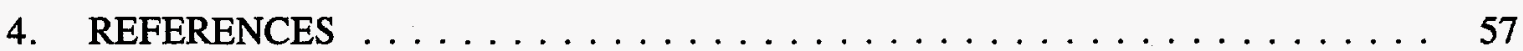

5. LIST OF AGENCIES AND PERSONS CONSULTED $\ldots \ldots \ldots \ldots \ldots \ldots$

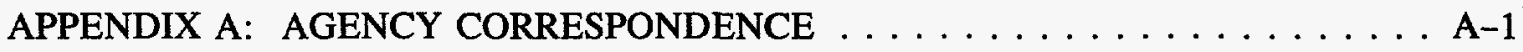


APPENDIX B: ASSUMPTIONS, CONSTRAINTS, AND LIMITATIONS IN THE ANALYSIS OF ACCIDENTAL ATMOSPHERIC RELEASES OF URANIUM B-1 


\section{LIST OF FIGURES}

Figure

Page

1.1. Location of Nuclear Metals, Inc. (NMI) in eastern Massachusetts . . . . . . . . . 3

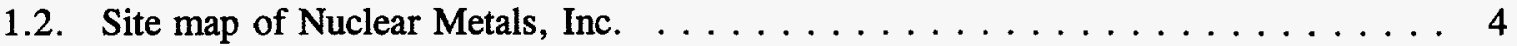

2.1. First floor layout of process areas within buildings at Nuclear Metals, Inc. . . . . . 11

3.1. Windrose for Nuclear Metals, Inc., recorded at a height of $18 \mathrm{~m} \mathrm{(59 \textrm {ft } )}$ between January 1993 and December 1994 . . . . . . . . . . . . . . . . . . . 17

\section{LIST OF TABLES}

Table

3.1. Ambient air quality data from monitors located near Nuclear Metals, Inc. . . . . 18

3.2. Emission rates of depleted uranium in 1994 at Nuclear Metals, Inc. (NMI) . . . . 20

3.3. Maximum allowable emission rates of criteria pollutants for Nuclear Metals, Inc. . . . . . . . . . . . . . . . . . . . . . . . 24

3.4. Boiler stack parameters at Nuclear Metals, Inc. used as input for the ISC2 model . . . . . . . . . . . . . . . . . . . . . . 25

3.5. Maximum predicted concentrations of criteria pollutants from boiler emissions at Nuclear Metals, Inc. compared to the National Ambient Air Quality Standards (NAAQS)

3.6. Maximum quantities of depleted uranium historically located in process-specific areas at Nuclear Metals, Inc. (NMI) . . . . . . . . . . . . . . 30

3.7. Values for input parameters used in the accident analysis for Nuclear Metals, Inc. . . . . . . . . . . . . . . . . . . . . . . . 36

3.8. Quantities of depleted uranium potentially inhaled by an exposed individual in the event of a severe fire at Nuclear Metals, Inc. facilities (based on historical quantities)

3.9. Doses from depleted uranium to a nearby exposed individual in the event of a severe fire at Nuclear Metals, Inc. facilities (based on historical quantities)

3.10. Volumes of acids present at Nuclear Metals, Inc. facilities and corresponding quantities of the hazardous substances contained within the acid solutions

3.11. Maximum predicted concentrations and related exposure limits associated with acid hazards at Nuclear Metals, Inc. facilities . . . . . . . . . . . 46

3.12. Racial and ethnic composition of towns within a four-mile radius of Nuclear Metals, Inc.

3.13. Income distribution in dollars per household for towns within a four-mile radius of Nuclear Metals, Inc. 



\section{ACRONYMS AND ABBREVIATIONS}

$\begin{array}{ll}{ }^{\circ} \mathrm{C} & \text { degrees Celsius } \\ \mathrm{CEQ} & \text { Council on Environmental Quality } \\ \mathrm{CFR} & \text { Code of Federal Regulations } \\ \mathrm{Ci} & \text { curie } \\ \mathrm{cm} & \text { centimeter } \\ \mathrm{CNC} & \text { computerized numerical control } \\ \mathrm{CO} & \text { carbon monoxide } \\ \mathrm{CREW} & \text { Citizen's Research and Environmental Watch } \\ \mathrm{DOE} & \text { U. S. Department of Energy } \\ \mathrm{DR} & \text { damage ratio } \\ \mathrm{EA} & \text { Environmental Assessment } \\ \mathrm{EIS} & \text { Environmental Impact Statement } \\ \mathrm{EPA} & \text { U. S. Environmental Protection Agency } \\ \mathrm{ERPG} & \text { Emergency Response Planning Guideline } \\ { }^{\circ} \mathrm{F} & \text { degrees Fahrenheit } \\ \mathrm{FONSI} & \text { Finding of No Significant Impact } \\ \mathrm{fpm} & \text { feet per minute } \\ \mathrm{FR} & \text { Federal Register } \\ \mathrm{ft} & \text { foot } \\ \mathrm{g} & \text { gram } \\ \text { gal } & \text { gallon } \\ \mathrm{gph} & \text { gallons per hour } \\ \mathrm{gpm} & \text { gallons per minute } \\ \mathrm{H}{ }_{2} \mathrm{SO} \mathrm{H}_{4} & \text { sulfuric acid } \\ \mathrm{ha} & \text { hectare } \\ \mathrm{HBF} & \text { fluoroboric acid } \\ \mathrm{HCl} & \text { hydrogen chloride (also hydrochloric acid) } \\ \mathrm{HF} & \text { hydrogen fluoride (also hydrofluoric acid) } \\ \mathrm{hr} & \text { hour } \\ \mathrm{ICRP} & \text { International Committee on Radiation Protection } \\ \mathrm{IDLH} & \text { immediately dangerous to life and health } \\ \text { in. } & \text { inch } \\ \mathrm{ISC} 2 & \text { Industrial Source Complex-Version } 2 \text { air dispersion model } \\ \mathrm{K} & \text { degrees Kelvin } \\ \mathrm{kg} / \mathrm{m}^{3} & \text { kilograms per cubic meter } \\ \mathrm{kg} / \mathrm{s} & \text { kilograms per second } \\ \mathrm{L} & \text { liter } \\ \mathrm{L} / \mathrm{s} & \text { liters per second } \\ \mathrm{lb} & \text { pound } \\ & \end{array}$


$\mathrm{LC}_{50} \quad$ concentration which would result in fatalities to 50 percent of the exposed population

m meter

$\mathrm{m} / \mathrm{s} \quad$ meters per second

$\mathrm{m}^{3} \quad$ cubic meters

$\mathrm{mg} \quad$ milligram

$\mathrm{mg} / \mathrm{m}^{3} \quad$ milligrams per cubic meter

MIT Massachusetts Institute of Technology

mph miles per hour

$\mu \mathrm{Ci} \quad$ microcurie

$\mu \mathrm{Ci} / \mathrm{kg} \quad$ microcuries per kilogram

$\mu \mathrm{g} / \mathrm{m}^{3} \quad$ micrograms per cubic meter

$\mu \mathrm{m} \quad$ micrometer

mrem millirem

$N \quad$ normal

NAAQS National Ambient Air Quality Standards

NEPA National Environmental Policy Act

NESHAP National Emissions Standards for Hazardous Air Pollutants

NIOSH National Institute of Occupational Safety and Health

NMI Nuclear Metals, Incorporated

NMSS Nuclear Material Safety and Safeguards

$\mathrm{NO}_{2} \quad$ nitrogen dioxide

NRC Nuclear Regulatory Commission

NUREG Nuclear Regulatory Commission Regulation

$\mathrm{O}_{3} \quad$ ozone

ORNL Oak Ridge National Laboratory

$\mathrm{pCi} / \mathrm{g} \quad$ picocuries per gram

$\mathrm{Pb} \quad$ lead

PG Pasquill-Gifford

PM-10 particulate matter with aerodynamic diameter less than 10 micrometers

PSD prevention of significant deterioration

qtr quarter

rem roentgen equivalent in man

$\mathrm{rem} / \mu \mathrm{Ci} \quad$ rems per microcurie

$r_{f} \quad$ respirable fraction

$R F \quad$ release fraction

$\mathrm{s} / \mathrm{m}^{3} \quad$ seconds per cubic meter

$\mathrm{s} \quad$ second

$\mathrm{SO}_{2} \quad$ sulfur dioxide

$\mathrm{UF}_{4} \quad$ uranium tetrafluoride

$\mathrm{UF}_{6} \quad$ uranium hexafluoride

y year 


\section{EXECUTIVE SUMMARY}

The U.S. Nuclear Regulatory Commission (NRC) has prepared this Environmental Assessment (EA) to evaluate environmental issues associated with the renewal of licenses issued by NRC for facilities operated by Nuclear Metals, Inc. (NMI) in Concord, Massachusetts. By renewing the licenses, NRC proposes to allow the continuation of ongoing operations involving radioactive materials at NMI's facilities. This EA focuses on the potential impacts related to air emissions at NMI during normal (incident-free) operations and accidental releases.

Results indicate that impacts to atmospheric resources associated with radionuclide emissions during incident-free operations at NMI would be minor, and impacts to the public from exposure to uranium concentrations in soils are expected to be minimal. With regard to nonradiological emissions during normal operations, modeling results for sulfur dioxide $\left(\mathrm{SO}_{2}\right)$ emissions from the boilers indicate that the potential exists for exceeding the short-term National Ambient Air Quality Standards (NAAQS), a condition that would correspond to considerable impact on local air quality. NMI is prepared to undertake mitigative action to prevent potential exceedances of the short-term $\mathrm{SO}_{2} \mathrm{NAAQS}$, and the Massachusetts Department of Environmental Protection is prepared to resolve the issue via a permit/approval change or through a Consent Order. For all other criteria pollutants, maximum concentrations are predicted to be less than the NAAQS, and local air quality effects associated with these pollutants would be minor.

In the unlikely event of a severe fire, NMI's commitment to limit the depleted uranium inventory and their requested level for the natural uranium inventory ensure that no major impacts would result from the radiological or chemical effects of uranium released to the atmosphere. However, for the same fire, predicted sulfuric acid $\left(\mathrm{H}_{2} \mathrm{SO}_{4}\right)$ concentrations based on conservative (upper bound) modeling exceed the Emergency Response Planning Guideline (ERPG) levels. NMI has committed to NRC to give a briefing for local emergency response officials regarding the potential for an accidental $\mathrm{H}_{2} \mathrm{SO}_{4}$ release.

The EA analyzes environmental justice issues to a lesser extent, commensurate with the potential for impacts. Findings indicate that there is no potential for concern based on race, ethnicity, or income. 


\section{INTRODUCTION}

\subsection{PURPOSE OF AND NEED FOR THE PROPOSED ACTION}

This Environmental Assessment (EA) has been prepared by the U.S. Nuclear Regulatory Commission (NRC), in compliance with the National Environmental Policy Act (NEPA) of 1969 , to evaluate environmental issues associated with the renewal of licenses issued by NRC for facilities operated by Nuclear Metals, Inc. (NMI) in Concord, Massachusetts. The purpose of NRC's proposed action (i.e., license renewal) is to permit the continuation of ongoing operations involving radioactive materials at NMI's facilities. Activities at NMI include the development and manufacture of castings, extrusions, machined parts, and metal powders comprised of depleted uranium and natural uranium metal, both of which are radioactive. Depleted uranium is a by-product material of the uranium enrichment process performed at other facilities to obtain material with a higher percentage of U-235. NMI is licensed to combine depleted uranium wastes generated at NMI with sand contaminated with depleted uranium (obtained from other licensees) to form a solidified mixture. By using contaminated sand rather than virgin sand, the total quantity of low-level radioactive waste sent to commercial burial sites is minimized because the contaminated sand does not need to be sent separately in addition to the solidified mixture.

NRC license renewal is needed to permit the continuation of NMI operations involving radioactive materials. Specialized products composed of depleted uranium and natural uranium have many important military, aerospace, industrial, and medical applications. About half of the U.S. demand for these products is being met by operations at the NMI facilities. Without NMI operations, the demand for these products may exceed their supply. A shortage of these products could compromise national security and adversely affect health care. 


\subsection{BACKGROUND INFORMATION ON NUCLEAR METALS, INC.}

NMI is located in Concord, Massachusetts, approximately $31 \mathrm{~km}$ (19 miles) northwest of Boston (Figure 1.1). The facility occupies approximately 18.5 ha (45.7 acres) of land, about $50 \mathrm{~m}$ (165 ft) south of the Assabet River (Figure 1.2). NMI began operations in 1942 as part of metallurgical research and development activities for the Manhattan Project at the Massachusetts Institute of Technology (MIT). These activities were transferred to private ownership in 1954 and were moved from the MIT campus in Cambridge, Massachusetts to this location in 1958. The NMI facilities originally consisted of Buildings A, B, and C. Buildings D and E were added in 1978 and 1983, respectively (Figure 1.2).

Approximately 38 percent of current activities at NMI are subject to NRC licensing. NMI presently operates under two NRC licenses (License Nos. SMB-179 and SUB-1452). On April 28, 1989, NMI submitted a renewal application to NRC for its process license, SMB-179, prior to the expiration date of May 31, 1989. On February 26, 1990, NMI submitted a renewal application to NRC for License No. SUB-1452, prior to the expiration date of March 31, 1990. Pursuant to the "deemed timely" provision of 10 CFR 2.109(a), NMI is authorized to continue operating beyond the expiration dates under the conditions of the existing licenses until NRC makes a decision on NMI's renewal applications. A revised license renewal application for both licenses was submitted to NRC by NMI on September 6, 1996. If renewed, the licenses would be effective for at least five years.

All current activities that are subject to NRC licensing involve uranium metal processing, which presently is licensed under NRC License No. SMB-179. Depleted uranium metal is processed to form armor penetrators used by the U. S. Department of Defense and authorized export countries. NMI also uses depleted uranium in the manufacture of aircraft counterweights and radiation shielding devices, and in the production of bulk ingots. All of these processes require melting the uranium metal in the foundry area and pouring it into molds or extruding it into rods. Subsequent cutting, grinding, and lathe operations are required to make the final products.

Prior to September 1985, metal processing activities generated liquid and sludge wastes containing depleted uranium and nitric acid. The nitric acid waste resulted from its use in 

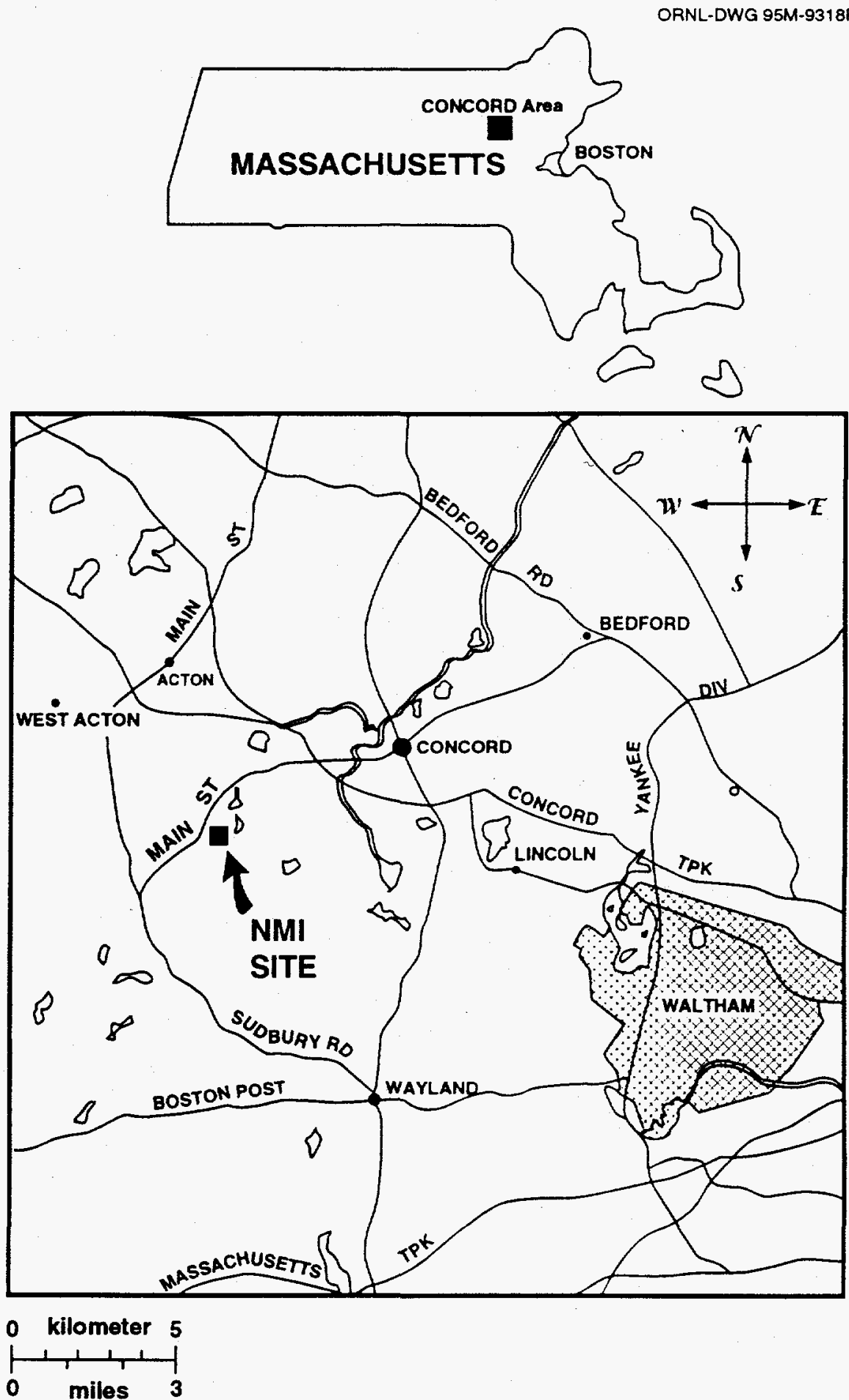

Figure 1.1. Location of Nuclear Metals, Inc. (NMI) in eastern Massachusetts. 
ORNL-DWG 95M-9317R

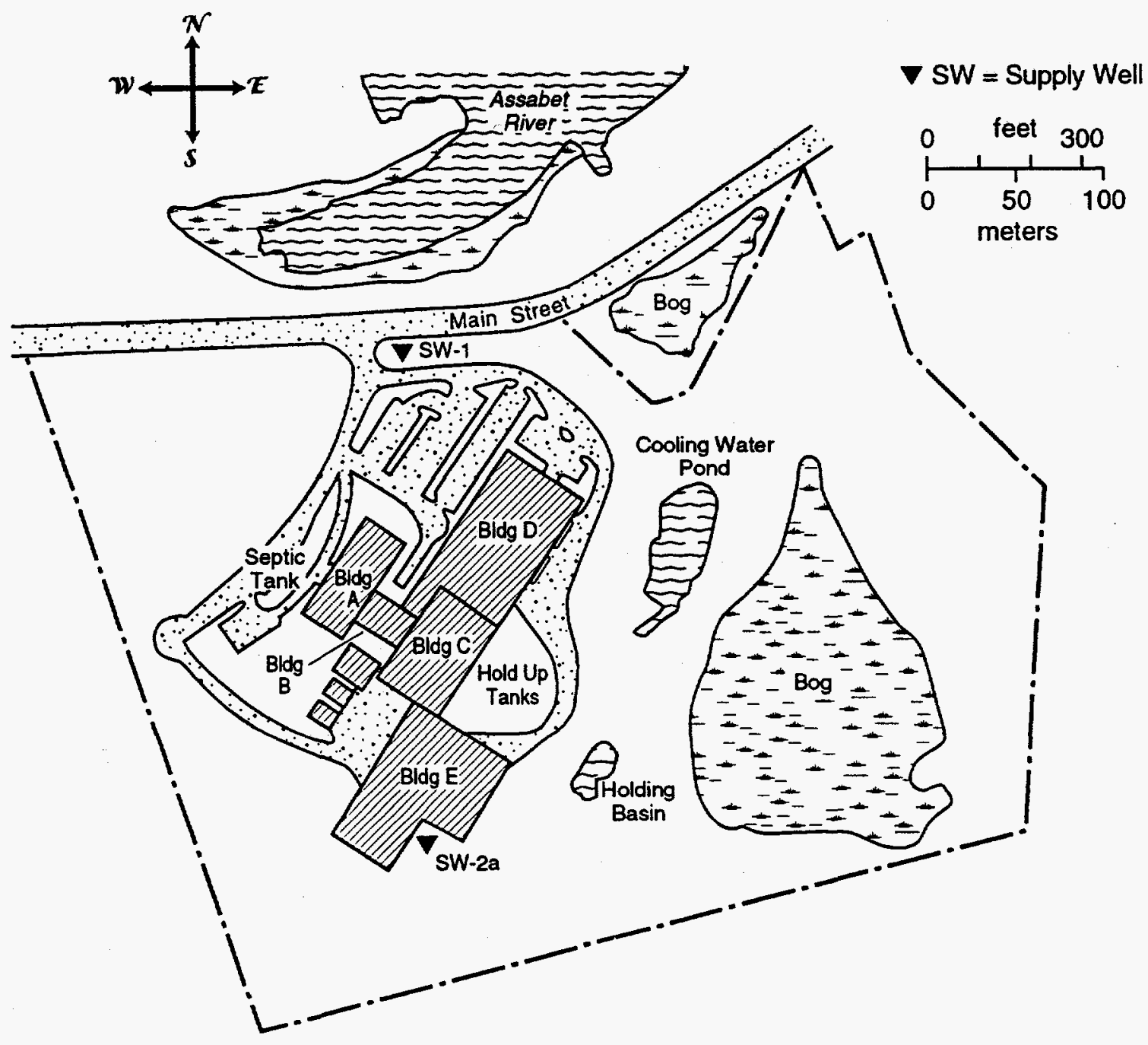

Figure 1.2. Site map of Nuclear Metals, Inc. 
removing metal jackets from depleted uranium extrusion billets. These liquid and sludge wastes were stabilized with lime because of their high acidity. Nitrate formed from the chemical reaction of nitric acid with the lime. The wastes were then emptied into an unlined holding basin and adjacent bog located on site property (Figure 1.2). This activity was discontinued in September 1985, and the holding basin was covered by an impermeable membrane in 1986 to reduce infiltration of rain water and discharge of contaminants to surface and ground waters.

An analysis of groundwater data collected from wells located on the site was conducted by NRC in 1994. This analysis concluded that groundwater at the site is contaminated with uranium and has the potential to migrate off the site in concentrations exceeding the current U.S. Environmental Protection Agency (EPA) drinking water standards for chemical uranium contamination (Byrne and Codell 1994). Elevated levels of nitrate have also been detected, but the concentrations about $18 \mathrm{~m}(60 \mathrm{ft})$ deep in the overburden have decreased appreciably both on and off the site over the last several years because nitrate migrates more quickly (and consequently is diluted more) than uranium. Nitrate found at about $150 \mathrm{~m}(500 \mathrm{ft})$ deep in the bedrock is migrating more slowly than in the overburden.

NRC requested the collection of additional data for further analyses to study options for remediation of the holding basin and contaminated groundwater (Byrne and Codell 1994). Currently, liquids used in depleted uranium processing are recycled. Small amounts of liquid wastes generated are dewatered by evaporation and the dried waste material is sent to an approved low-level radioactive waste disposal facility in Utah.

NMI is authorized to receive and process depleted uranium waste in contaminated sand, on contaminated metallic components, packaging materials, equipment, or as solids under NRC License No. SUB-1452. NMI has not performed any activities under this license for the past five years.

Approximately 62 percent of current operations at NMI involve processing of nonradioactive metals, primarily beryllium. Processing activities associated with these metals do not fall under the jurisdiction of the NRC license because they are nonradioactive and are not associated with the processing of depleted uranium. 


\subsection{SCOPE OF THE ENVIRONMENTAL ASSESSMENT}

As part of their initial review of NMI's license renewal application, NRC staff determined that an EA should be prepared to comply with NEPA. The purpose of this EA is to provide sufficient information and analysis for NRC to determine whether to prepare an Environmental Impact Statement (EIS) or to issue a Finding of No Significant Impact (FONSI). This approach is consistent with the Council on Environmental Quality regulations and NRC regulations for NEPA compliance [40 CFR 1501.4(a) and 10 CFR 51, respectively].

This EA focuses on the potential impacts associated with air emissions at NMI during normal (incident-free) operations and accidental releases. Air emissions are the primary pathway by which pollutants at NMI are released into the environment. This EA evaluates emissions of radionuclides and other pollutants associated with NRC license renewal. Air emissions of pollutants such as beryllium that are not associated with the NRC license renewal fall outside the scope of the EA and are not specifically considered herein. However, potential synergistic effects between emissions associated with non-licensed and licensed activities are considered within the context of cumulative impacts (Section 3.1.4).

Environmental justice is analyzed to a lesser extent, commensurate with the potential for impacts. Interim guidance provided in Policy and Procedures Letter 1-50, Revision 1, by NRC's Office of Nuclear Material Safety and Safeguards (NMSS) is to address environmental justice in "special case" EAs. Environmental justice is evaluated in this EA because NRC staff has decided that special circumstances exist at NMI given the existence of "substantial public interest" in NMI's request for license renewal. Because the proposed action involves continuing ongoing operations, other socioeconomic impacts are not expected and are not evaluated for the proposed action; however, the socioeconomic impacts of no action are briefly analyzed.

Other topics are not analyzed, except as warranted in the cumulative impacts section. The only release to surface water is stormwater runoff into the Assabet River. The only releases to groundwater are via (1) the septic system that is used for disposal of nonradioactive sanitary wastewater, and (2) groundwater recharge from the cooling pond that serves the non-contact 
cooling water system. Ecological resources are not expected to be affected by the proposed action because the action entails no disturbance of land or water resources, and no grounddisturbing activities. The U. S. Fish and Wildlife Service has been contacted regarding federally-listed or proposed, threatened and endangered species that potentially could be affected and has responded that no further consultation under Section 7 of the Endangered Species Act is required (see Appendix A). Similarly, the Massachusetts Natural Heritage and Endangered Species Program has been contacted regarding state-listed species and is not aware of any rare plants or animals or exemplary natural communities in the area (see Appendix A). The Massachusetts Historical Commission has been contacted under Section 106 of the National Historic Preservation Act and has determined that the continuation of ongoing NMI operations is unlikely to affect significant historic or archaeological resources (see Appendix A).

Remediation of the holding basin and contaminated groundwater is being planned as a separate decommissioning action; therefore, this action and subsequent environmental impacts are not addressed in this EA. However, potential environmental impacts associated with remedial activities combined with continuing operations are discussed within the context of cumulative impacts. 



\section{THE PROPOSED ACTION AND ALTERNATIVES}

This section describes the proposed action and the no-action alternative. Other alternatives have been considered and dismissed from further consideration because they are not reasonably foreseeable. No alternative sites are evaluated because NRC is limited to either renewing or not renewing the licenses at the existing NMI location. As another example of dismissed alternatives, delaying the license renewal would allow NMI to continue ongoing operations in accordance with 10 CFR 2.109(a), but would only defer an eventual decision; consequently, this alternative is not considered further.

\subsection{PROPOSED ACTION}

The proposed action is for NRC to approve NMI's revised application for renewal of NRC License Nos. SMB-179 and SUB-1452. The revised license renewal application submitted by NMI on June 3,1994, included a request to combine the two licenses into a single license. The renewed license would be effective for at least five years from the date of its issuance. Under the proposed action, ongoing operations at NMI's facility would be expected to continue without appreciable change from current operations for the duration of the renewed licensing period.

Existing License No. SMB-179 authorizes NMI to possess at any given time a maximum of $25,000 \mathrm{~kg}(55,000 \mathrm{lb})$ of natural uranium metal, alloy, or oxide; a maximum of $3,000,000 \mathrm{~kg}(6,600,000 \mathrm{lb})$ of depleted uranium metal, alloy, oxide, or fluoride; a maximum of $25,000 \mathrm{~kg}(55,000 \mathrm{lb})$ of natural thorium metal, alloy, or oxide; and a maximum of $50 \mathrm{~kg}$ $(110 \mathrm{lb})$ of depleted uranium slab. The license renewal application requests an increase to a maximum of $100,000 \mathrm{~kg}(220,000 \mathrm{lb})$ of natural uranium and a maximum of $5,000,000 \mathrm{~kg}$ $(11,000,000 \mathrm{lb})$ of depleted uranium. The licensed uranium may be an element of any compound except uranium hexafluoride $\left(\mathrm{UF}_{6}\right)$. Authorized uses of the first three types of materials include the manufacture and development of metallic products in such forms as 
derbies (i.e., hat-shaped ingots), castings, extrusions, machined parts, formed parts, metal powders, consolidated powder compacts, and uranium salts; distribution of these products to authorized users is also permitted. However, NMI has moved the production of derbies to its facility in Barnwell, South Carolina, and does not anticipate further production in Concord. The use of uranium slab as a calibration source for external dosimetry is no longer expected, and this item will be excluded from the new license. Additionally, storage and processing of thorium will be excluded from the new license.

Operations at NMI authorized by License No. SMB-179 include casting, extrusion, machining, forming, powder manufacture, and other miscellaneous activities. Figure 2.1 displays a more detailed layout of buildings at NMI and the location of various processing activities. The administrative areas are located in Buildings A and B. Additionally, two industrial boilers used for heating the entire NMI facility are located in Building B. Building $\mathrm{C}$ houses the machine shop, foundry, and extrusion activities for depleted uranium. Uranium fabrication activities, the acid pickling area, and computerized numerical control (CNC) machines are located in Building D. Charge preparation, waste treatment activities, and quality assurance for depleted uranium processing are conducted in Building E. The following sections describe processing activities associated with License No. SMB-179:

Casting operations. Feed material for casting operations may be received as derbies or as cut pieces of metal. Large quantities of feed material are stored in the charge preparation area of Building E. Additional cutting of the feed material may be performed before loading the crucible used in the melting process. All cutting activities use non-combustible liquid coolant and are vented and filtered to exhaust handling systems. Both alloyed and unalloyed castings are manufactured at NMI. A 2.5-hr casting cycle is typical. The melting and casting process is conducted inside electric induction furnaces under vacuum. A typical quantity for the melting process is $830 \mathrm{~kg}(1,800 \mathrm{lb})$ per furnace, and eight furnaces are available for simultaneous operation. The melt is poured into one or more molds and allowed to solidify. The furnace is opened and the mold or molds disassembled to retrieve the castings. The castings may represent a completed object as is, or they may require further processing, such as cutting, enhancement of surface finish, or painting/electroplating. The graphite crucible is 


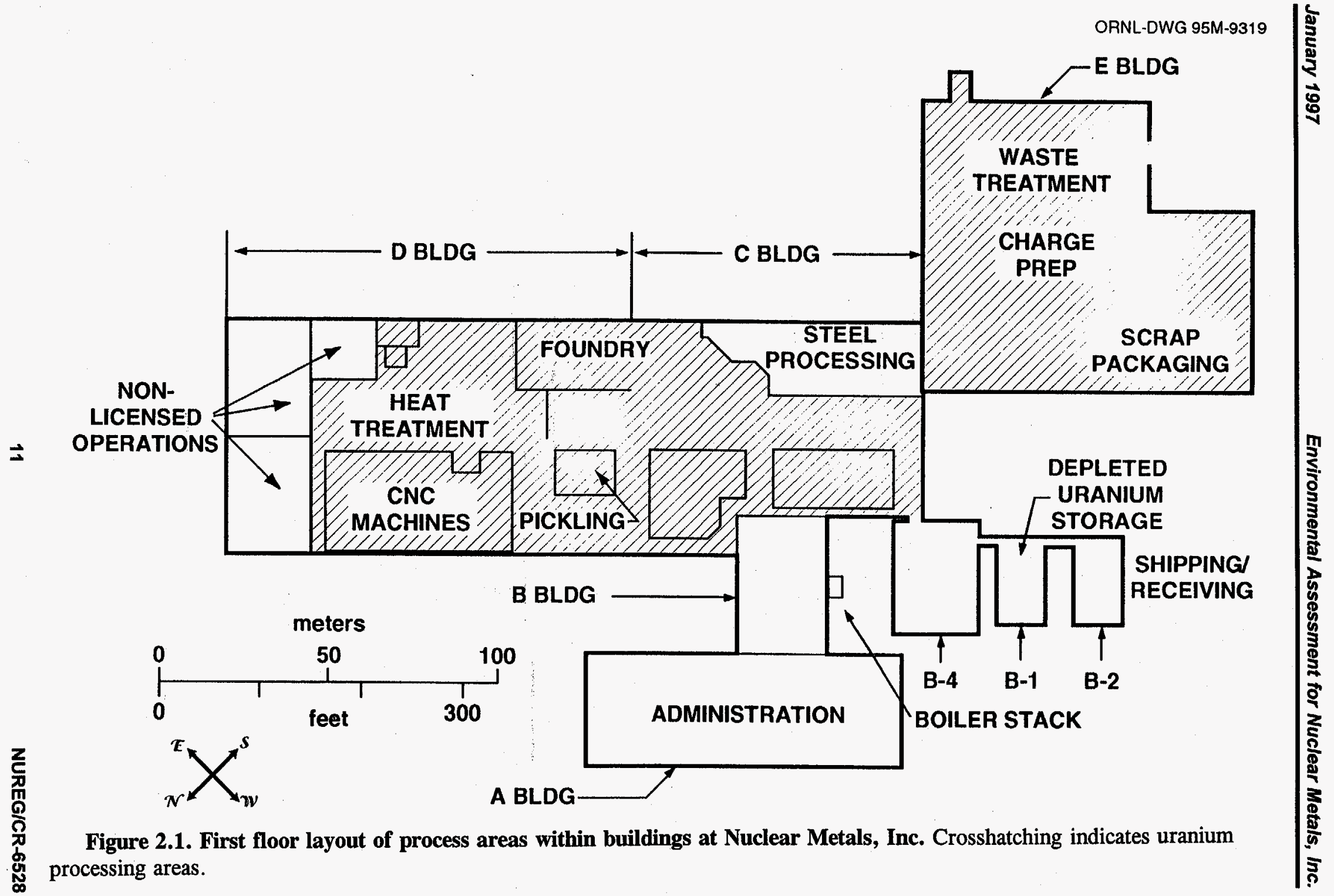


cleaned within appropriately vented enclosures to remove residues from the melting process. Prior to cleaning, the crucible may be stored for a period of time to allow for the decay of short-lived beta emitting radioactive decay products, such as Protactinium-234 (half life of $6.7 \mathrm{hr}$ ) and Thorium-234 (half life of 24 days).

Extrusion operations. Castings, as described above, or sections cut from stock are made into extrusion billets and are then enclosed in metal jackets to minimize oxidation or the spread of contamination; however, extrusion of unjacketed billets may also occur. Billet stock may be machined prior to encapsulation; all machining is performed with non-combustible liquid coolants in vented equipment. Encapsulated billets are heated by electric induction and extruded; the encapsulation remains as a thin layer protecting the surface of the extrusion. The jacketing may be subsequently removed in a sulfuric acid bath. Individual billets seldom exceed $180 \mathrm{~kg}(400 \mathrm{lb})$. As many as 50 billets may be extruded in one 8-hr shift.

Machining operations. Castings, extrusions, or formed pieces may require machining either as a preparatory operation to further processing or as a finishing operation. All machining equipment utilizes non-combustible liquid coolants and is appropriately vented. Most of the items subject to machining weigh less than $50 \mathrm{~kg}(110 \mathrm{lb})$. The chips from the machining and grinding operation are collected in 208-L (55-gal) drums which are partially filled with liquid coolant. No more than about $10 \mathrm{~kg}(22 \mathrm{lb})$ of uranium chips are allowed to collect in each drum. Chip wastes are eventually encapsulated in concrete for disposal.

Forming operations. Extrusions or cut pieces may be straightened, flattened, forged, or swaged. These operations may occur at either room temperature or at elevated temperatures. Individual pieces may weigh from less than $1 \mathrm{~kg}(2 \mathrm{lb})$ to as much as $100 \mathrm{~kg}(220 \mathrm{lb})$.

Powder manufacture. Solid metal bars may be converted to powder under an inert atmosphere with an apparatus designed to rotate the bars while melting them with the aid of an electric arc. The droplets that form then solidify within the apparatus. The product is 
relatively coarse and spherical. Powder manufacture is generally conducted in limited runs of a few hundred kilograms each.

Miscellaneous operations. Other operations include cleaning parts by immersion in acids or by contact with organic solvents or detergents. Acids may also be used to remove jacketing or metal-cladding materials.

Hydromet process. In addition to the activities described above, NMI has developed and may operate a system to recycle depleted uranium waste products using a hydrometallurgical process, which NMI calls the Hydromet process. Currently, however, the Hydromet process is not commercially viable. NRC previously modified License No. SMB-179 to include the Hydromet process as a fully permitted operation. The Hydromet process involves the dissolution of scrap metal in an aqueous solution of 20 percent hydrogen chloride $(\mathrm{HCl})$ and 2 percent fluoroboric acid $\left(\mathrm{HBF}_{4}\right)$, followed by the precipitation of $\mathrm{UF}_{4}$ (green salt) resulting from the addition of hydrogen fluoride (HF). The precipitated green salt is filtered, washed, dried, and heat treated, after which it is suitable for reduction to metal. The equipment performing the Hydromet process makes use of existing co-located service connections for ventilation, utilities, and wastewater treatment. No additional construction of buildings or disturbance of property was required for this project. The Hydromet facility is capable of annually processing $100,000 \mathrm{~kg}(220,000 \mathrm{lb})$ of depleted uranium waste metal.

License No. SUB-1452 authorizes NMI to possess a maximum of $1,000 \mathrm{~kg}(2,200 \mathrm{lb})$ of depleted uranium as contamination in sand; a maximum of $99,000 \mathrm{~kg}(217,800 \mathrm{lb})$ of depleted uranium as contamination on metallic components, packaging materials or equipment, or as waste solids; and a maximum of $10,000 \mathrm{~kg}(22,000 \mathrm{lb})$ of natural thorium as contamination on metallic components, packaging materials or equipment, or as waste solids. These materials are authorized to be received by NMI as waste for waste processing and/or repackaging and for transfer to an authorized recipient. Sand contaminated with depleted uranium after test firing depleted uranium armor penetrators is authorized to be obtained from other licensees and used in place of virgin sand in NMI's concrete plant. The purpose of the concrete plant is 
to solidify depleted uranium wastes generated at the facility. By using already-contaminated sand, the total amount of low-level radioactive waste sent to commercial burial sites can be reduced appreciably. Any process activities associated with License No. SUB-1452 would occur in Building E. Receipt of materials would occur in other buildings. NMI has not performed any activities under this license for the past five years.

\subsection{NO ACTION}

Under the no-action alternative, NRC would not renew NMI's licenses. Consequently, NMI operations involving radioactive materials would be discontinued and no products would be produced at the facility that are composed of depleted uranium and natural uranium (e.g., armor penetrators used by the U. S. Department of Defense, and radiation shielding used for medical and industrial applications). Since approximately half of the U.S. demand for these products is being met by operations at NMI facilities, the demand for these products may exceed their supply. A shortage of these products could compromise national security and adversely affect health care.

Although NMI has not performed any activities in the past five years associated with the waste processing and repackaging license, under the no-action alternative NMI would no longer be authorized for these activities. Thus, the option to conduct these activities in the future would not be available.

As a consequence of the no-action alternative, NMI would be expected to continue operating, but it would concentrate solely on processing of nonradioactive materials (e.g., beryllium) that do not require NRC licensing. For Fiscal Year 1995, these other activities accounted for 62 percent of NMI's revenue. About 50 percent of NMI personnel are employed for work involving these other activities. 


\section{ENVIRONMENTAL CONSEQUENCES}

This section analyzes the potential environmental impacts expected as a consequence of the proposed action and no-action alternative. As discussed in Section 1.3, detailed analyses focus on the expected level of impacts associated with air emissions. As a basis for evaluating impacts, the characteristics of the potentially affected environmental resources are described. Also included are discussions of cumulative impacts, such as those associated with the planned remediation of the holding basin and contaminated groundwater. Mitigation measures are also discussed.

\subsection{ENVIRONMENTAL CONSEQUENCES OF THE PROPOSED ACTION}

This section evaluates the potential impacts resulting from the proposed action. Included in the evaluation are all NMI activities under the renewed license that combines License Nos. SMB-179 and SUB-1452.

\subsubsection{Incident-free Atmospheric Releases}

Both radiological and nonradiological atmospheric emissions occur during normal (incident-free) operations at NMI. The following impact assessment of normal atmospheric releases is divided into three sections: (1) background information on climatology and air quality, (2) radiological impacts, and (3) nonradiological impacts. 


\subsubsection{Climatology and air quality}

The climate of eastern Massachusetts is affected by three different air mass types: (1) cold, dry air that flows from the Canadian interior, (2) warm, moist air that flows from the Atlantic Ocean and the Gulf of Mexico, and (3) cool, damp air that flows from the North Atlantic. Onsite meteorological data include temperatures and winds recorded at a height of $18 \mathrm{~m}(59 \mathrm{ft})$ above ground level. Temperature extremes recorded at NMI between January 1993 and December 1994 ranged from $-23^{\circ} \mathrm{C}$ to $37^{\circ} \mathrm{C}\left(-9^{\circ} \mathrm{F}\right.$ to $\left.98^{\circ} \mathrm{F}\right)$. The average temperature recorded over this period was $9.6^{\circ} \mathrm{C}\left(49^{\circ} \mathrm{F}\right)$. The prevailing winds measured at NMI are generally from the west. Figure 3.1 displays a wind rose ${ }^{*}$ for winds recorded at NMI between January 1993 and December 1994.

The average annual precipitation recorded at the Logan International Airport [located about $25 \mathrm{~km}$ (16 miles) to the east-southeast of the site] is about $110 \mathrm{~cm}$ (43 in.) (water equivalent). Precipitation is fairly even throughout the year, with highest amounts occurring in the cold seasons (November to March). The average annual snowfall at Logan International Airport is about $105 \mathrm{~cm}$ (41 in.).

National Ambient Air Quality Standards (NAAQS) exist for the following criteria pollutants: particulate matter less than $10 \mu \mathrm{m}$ in diameter (inhalable particulate matter, known as PM-10), sulfur dioxide $\left(\mathrm{SO}_{2}\right)$, nitrogen dioxide $\left(\mathrm{NO}_{2}\right)$, carbon monoxide $(\mathrm{CO})$, ozone $\left(\mathrm{O}_{3}\right)$, and lead $(\mathrm{Pb})$. Massachusetts has adopted the NAAQS as the state standards. The entire state is designated as being in "serious" nonattainment for $\mathrm{O}_{3}(40 \mathrm{CFR} 81.322)$. Serious $\mathrm{O}_{3}$ nonattainment indicates that maximum 1-hr ambient concentrations may be between 270 and $313 \mu \mathrm{g} / \mathrm{m}^{3}$ in the nonattainment region. Additionally, the western portion of Middlesex County, in which Concord is located, is in unclassifiable/attainment status for CO (i.e., the area is believed to be in attainment, but no data are available to support this conclusion). However, the rest of Middlesex County and the entire Boston metropolitan area are

\footnotetext{
${ }^{*} \mathrm{~A}$ wind rose is a graph in which the frequency of wind blowing from each direction is plotted as a bar that extends from the center of the diagram. Wind speeds are denoted by bar widths and shading; the frequency of wind speed classes within each direction is depicted according to the length of the corresponding section of the bar. Note that the wind rose displays directions from which the wind originates, emissions would travel downwind in the opposite direction.
} 
ORNL-DWG 95M-9316

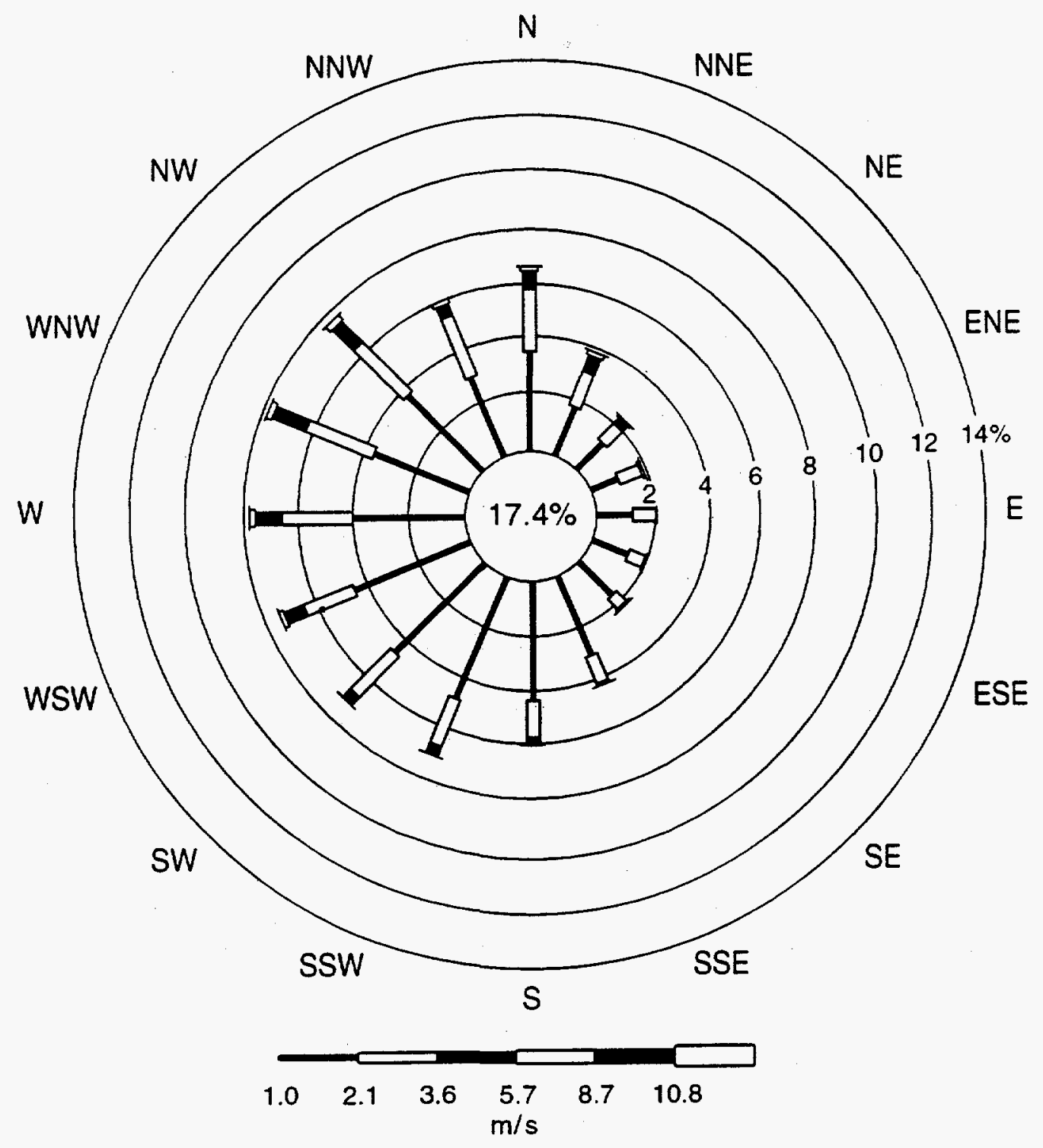

Figure 3.1. Windrose for Nuclear Metals, Inc., recorded at a height of $18 \mathrm{~m} \mathrm{(59} \mathrm{ft)}$ between January 1993 and December 1994. Value in center indicates percent of time that wind is calm (i.e., less than $0.5 \mathrm{~m} / \mathrm{s}$ ). 
designated as being in "moderate" nonattainment for $\mathrm{CO}$. Moderate $\mathrm{CO}$ nonattainment indicates that maximum 8 -hr ambient concentrations may be between 10,000 and $14,600 \mu \mathrm{g} / \mathrm{m}^{3}$ in the nonattainment region. The area around Boston, including Concord, is in attainment for $\mathrm{SO}_{2}, \mathrm{NO}_{2}, \mathrm{PM}-10$, and $\mathrm{Pb}$. Table 3.1 shows ambient air quality data from monitors near NMI that are maintained and operated by the Massachusetts Department of Environmental Protection, and compares the data with the NAAQS.

In addition to air emissions monitoring, NMI operates and maintains eight ambient air radionuclide monitors, located on the site and at the site perimeter. During the five-year

Table 3.1 Ambient air quality data from monitors located near Nuclear Metals, Inc.

\begin{tabular}{|c|c|c|c|c|c|}
\hline Pollutant & $\begin{array}{l}\text { Monitor } \\
\text { location }\end{array}$ & $\begin{array}{l}\text { Averaging } \\
\text { time }\end{array}$ & $\begin{array}{l}\text { Concentration } \\
\qquad\left(\mu \mathrm{g} / \mathrm{m}^{3}\right)\end{array}$ & $\begin{array}{c}\text { NAAQS }^{a} \\
\left(\mu \mathrm{g} / \mathrm{m}^{3}\right)\end{array}$ & $\begin{array}{c}\text { Percent of } \\
\text { standard }\end{array}$ \\
\hline \multirow[t]{3}{*}{$\mathrm{SO}_{2}{ }^{a}$} & \multirow[t]{3}{*}{ Waltham } & 3-hr & $181^{b}$ & 1,300 & 14 \\
\hline & & 24-hr & $92^{b}$ & 365 . & 25 \\
\hline & & annual & $16^{c}$ & 80 & 20 \\
\hline $\mathrm{NO}_{2}{ }^{a}$ & $\begin{array}{l}\text { Boston } \\
\text { (Kenmore) }\end{array}$ & annual & $64^{c}$ & 100 & 64 \\
\hline \multirow[t]{2}{*}{$\mathrm{PM}-10^{a}$} & \multirow[t]{2}{*}{ Sudbury } & 24-hr & $62^{b}$ & 150 & 41 \\
\hline & & annual & $16^{c}$ & 50 & 32 \\
\hline \multirow[t]{2}{*}{$\mathrm{CO}^{a}$} & \multirow{2}{*}{$\begin{array}{l}\text { Boston } \\
\text { (Kenmore) }\end{array}$} & 1-hr & $9,085^{b}$ & 40,000 & 23 \\
\hline & & 8-hr & $5,750^{b}$ & 10,000 & 57 \\
\hline $\mathrm{O}_{3}{ }^{a}$ & Sudbury & $1-\mathrm{hr}$ & $261^{b}$ & 235 & 111 \\
\hline $\mathrm{Pb}^{a}$ & $\begin{array}{l}\text { Boston } \\
\text { (Kenmore) }\end{array}$ & calendar qtr & $0.03^{b}$ & 1.5 & 2 \\
\hline
\end{tabular}

aAbbreviations: NAAQS = National Ambient Air Quality Standards; $\mathrm{SO}_{2}=$ sulfur dioxide; $\mathrm{NO}_{2}=$ nitrogen dioxide; PM-10 = inhalable particulate matter with aerodynamic diameter of $10 \mu \mathrm{m}$ or less; $\mathrm{CO}=$ carbon monoxide; $\mathrm{O}_{3}=$ ozone; $\mathrm{Pb}=$ lead.

${ }^{b}$ Maximum measured concentration during January 1992-December 1993.

${ }^{c}$ Maximum annual average for 1992-1993. 
period of 1988-1992, the maximum ambient uranium concentration on an annual average was about $4 \times 10^{-10} \mu \mathrm{Ci} / \mathrm{m}^{3}$ (GZA 1994a).

\subsubsection{Radiological impacts}

Public health and safety. The following analysis first considers emissions of radionuclides from the NMI facility and compares these emissions to limits set by the town of Concord because the NRC does not explicitly set emission limits. The analysis then uses atmospheric dispersion modeling to estimate ambient annual dose to the public resulting from emissions at the NMI facility. These estimated annual doses are compared to NRC requirements and EPA standards to gauge impacts to public health and safety.

Small amounts of uranium are emitted from 33 stacks at NMI. The town of Concord permits depleted uranium emissions of up to $280 \mu \mathrm{Ci}$ per calendar quarter for operations associated with License Nos. SMB-179 and SUB-1452 (Condition 12 specified in the town of Concord's special building permit for NMI Building $E$ issued in 1982). As shown in Table 3.2, emission rates of depleted uranium in 1994 were less than 60 percent of the $280 \mu \mathrm{Ci}$ per calendar quarter limit (French 1995).

To assess the impact of uranium emissions on atmospheric resources, the COMPLY computer code was used to determine the maximum annual dose equivalent received from uranium concentrations in the ambient air (at or beyond the site boundary). The COMPLY computer code is approved by EPA for use as a screening model by NRC-licensed facilities to determine compliance with the National Emissions Standards for Hazardous Air Pollutants (NESHAP) limit of $10 \mathrm{mrem} / \mathrm{y}$ for whole-body dose from air emissions only (EPA 1989). This limit was promulgated by EPA to ensure that radionuclide emissions from a facility would not exceed amounts that would cause any member of the public to receive, from all radionuclides collectively, an annual committed effective dose equivalent of $10 \mathrm{mrem}$ (40 CFR 61.92).

For the modeling, annual emissions were assumed to be at maximum permitted levels (i.e., $1,120 \mu \mathrm{Ci} / \mathrm{y}$ as specified in Condition 12 in the town of Concord's special building permit for NMI Building E). All emissions were modeled to occur from one point source 
Table 3.2. Emission rates of depleted uranium in 1994 at Nuclear Metals, Inc. (NMI)

\begin{tabular}{lccc}
\hline Period & $\begin{array}{c}\text { Total depleted } \\
\text { uranium emissions } \\
(\mu \mathrm{Ci})\end{array}$ & $\begin{array}{c}\text { Maximum } \\
\text { allowable } \\
(\mu \mathrm{Ci})^{a}\end{array}$ & $\begin{array}{c}\text { Percent of } \\
\text { maximum } \\
\text { allowable }\end{array}$ \\
\hline 1st qtr & 59 & 280 & 21 \\
2nd qtr & 157 & 280 & 56 \\
3rd qtr & 122 & 280 & 44 \\
4th qtr & $\underline{128}$ & $\underline{280}$ & $\underline{46}$ \\
Total & 466 & 1,120 & 42 \\
\hline
\end{tabular}

${ }^{a}$ Condition 12 specified in the town of Concord's special building permit for NMI Building E, 1982.

located flush at roof level [10 $\mathrm{m}(33 \mathrm{ft})]$. The model also estimated the effects of the building wake. The building width used in the model was the maximum projected building width of all buildings located at the site, which is equal to about $235 \mathrm{~m}(771 \mathrm{ft})$. The above assumptions are conservative in that they result in higher predicted doses than are expected to occur.

The COMPLY computer code allows for four levels of screening, with Level 1 predicting the highest doses and Level 4 predicting the lowest doses. Each level is still conservative enough to be used for screening. A Level 2 screening was chosen for this analysis because it is the level that has the most conservative screening criteria, while allowing for input of annual stack emissions.

The maximum annual committed effective dose equivalent predicted using a Level 2 analysis was 2.5 mrem, which is 25 percent of the NESHAP. This dose was estimated to occur at a receptor located $150 \mathrm{~m}(492 \mathrm{ft})$ from the nearest building. Distances less than $150 \mathrm{~m}$ (492 $\mathrm{ft}$ ) were excluded due to the effect of the large building width on the COMPLY code. At downwind distances less than $150 \mathrm{~m}$ (492 ft), dose estimates made by the model are not reliable because the receptor would be located in the downwind recirculation cavity 
created by the building. The COMPLY code does not have an algorithm for estimating dose in the downwind recirculation cavity. Although a $150-\mathrm{m}(492-\mathrm{ft})$ receptor distance is about

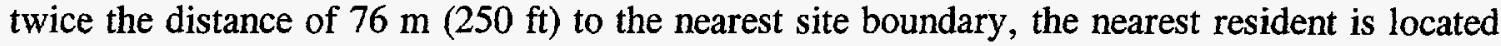
$240 \mathrm{~m} \mathrm{(790} \mathrm{ft)} \mathrm{from} \mathrm{the} \mathrm{nearest} \mathrm{building,} \mathrm{and} \mathrm{is} \mathrm{estimated} \mathrm{to} \mathrm{receive} \mathrm{a} \mathrm{smaller} \mathrm{dose} \mathrm{than} \mathrm{at}$

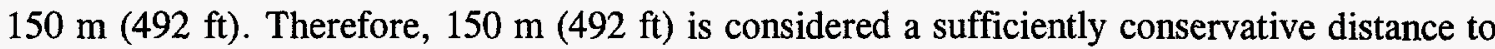
form an upper bound of doses that may be received by the public annually.

NRC requires that the total effective dose equivalent to individual members of the public resulting from operations of its licensees not exceed $100 \mathrm{mrem} / \mathrm{y}$ from all environmental transport pathways (10 CFR 20.1301). The atmospheric pathway is the only pathway by which radionuclides are released into the environment from NMI. Therefore, the predicted annual dose from atmospheric emissions is also the total dose received from all environmental pathways and can be compared to this standard directly. The predicted annual dose of $2.5 \mathrm{mrem}$ is 2.5 percent of the NRC total effective dose equivalent.

NRC also requires that an external effective dose equivalent to individual members of the public resulting from operations of its licensees not exceed $50 \mathrm{mrem} / \mathrm{y}$ from all environmental transport pathways (10 CFR 20.1302). Uranium is essentially the only radioactive material released to the atmosphere. Depleted uranium is mostly of concern as an internal dose from the inhalation/ingestion pathway because the primary decay particles are alpha particles. These decay particles can damage a cell if a uranium atom undergoes radioactive decay while in a cell. Because alpha particles cannot go through a piece of paper, clothing, or much air, when a uranium atom decays in the air surrounding a person, the resulting radiation dose is much less than the dose for the inhalation pathway. Therefore, almost no external dose would be received from atmospheric emissions.

As a further comparison, the maximum dose received by the public from NMI emissions would be less than 1 percent of that received annually from naturally occurring sources. Assuming that the maximum concentration of $4 \times 10^{-10} \mu \mathrm{Ci} / \mathrm{m}^{3}$ measured at the NMI radionuclide monitoring network (see Section 3.1.1.1) consisted entirely of U-238 and that a person breathes at a rate of approximately $8,390 \mathrm{~m}^{3}$ of air per year (ICRP 1994), the annual committed effective dose equivalent from the inhalation pathway corresponding to this air concentration is about 0.4 mrem. This value may be compared with an estimated 300 mrem 
average annual total dose equivalent received in the United States from natural background radiation (including a contribution from radon of about $200 \mathrm{mrem}$ ) (NCRP 1987). Based on these comparisons, the impacts to atmospheric resources associated with radionuclide emissions during incident-free operations at NMI would be minor.

Soil deposition. Small amounts of uranium particles emitted from NMI settle on surrounding soil surfaces. A sampling study conducted for NRC in 1983 (ORAU 1983) showed that uranium concentrations in offsite samples of surface soils did not exceed the range of area background levels [about 1 picocurie of uranium per gram of dry soil (pCi/g)]. Although this study found elevated levels of uranium in the soils on the site (as much as $2,711 \mathrm{pCi} / \mathrm{g}$ ), these concentrations were located near the septic system and probably resulted from subsurface water transport, not transport via the atmospheric pathway. Onsite surface soil samples collected in 1990 (Haley and Aldrich 1990) indicated that uranium levels were above area background levels, but were still below the NRC limit of $35 \mathrm{pCi} / \mathrm{g}$ that allows for unrestricted use of sites with minimal surface contamination from depleted uranium (i.e., this limit would apply if NMI's license was terminated and the site was released for unrestricted use) (46 FR 52061-63). This second study did not sample uranium concentrations in offsite surface soils. A third study conducted in 1993 (GZA 1994b) also measured onsite surface soil concentrations of uranium. The study found that uranium concentrations were below the $35 \mathrm{pCi} / \mathrm{g}$ limit for all but seven sampling locations. Seven samples taken directly below a former hazardous waste storage area revealed surface soil concentrations of uranium ranging from about $38 \mathrm{pCi} / \mathrm{g}$ to $181 \mathrm{p} / \mathrm{Ci} / \mathrm{g}$. Most of this contamination is attributed to past runoff from surface waters, not from deposition of atmospheric uranium emissions. GZA did not sample offsite surface soils for uranium.

A local citizens group, Citizen's Research and Environmental Watch (CREW), conducted an independent study in April 1994 to determine soil surface concentrations of uranium in the vicinity of NMI. The study took several samples at distances up to $1.2 \mathrm{~km}$ ( $0.75 \mathrm{mile})$ from the facility boundary and found that while soil concentrations did exceed area background levels, they were within the NRC limit of $35 \mathrm{pCi} / \mathrm{g}$ (CREW 1994). In October 1994, NRC took soil samples at the same locations as the CREW study and, with the exception of one 
sampling location, found that soil concentrations were at area background levels. The one location where the concentration exceeded area background levels was located just inside the perimeter of NMI and this concentration was less than half of the NRC limit of $35 \mathrm{pCi} / \mathrm{g}$ (NRC 1995). In December 1995, NRC collected 28 soil samples from offsite locations in the vicinity of NMI. All results were below the NRC release criteria for residual contamination (NRC 1996). In spite of some differences in results, the studies have indicated that levels of uranium contamination are below NRC limits for unrestricted public access; therefore, impacts to members of the public from exposure to soils are expected to be minimal.

Worker health and safety. Sources of exposure to radiological hazards are managed at NMI so that workers receive less radiation dose than permitted by federal guidelines for radiation dose to occupational personnel. Traditional health physics practices, including the defining of restricted areas, are used to limit occupational exposures. Restricted areas have been established around equipment machining source material and where castings are made. Localized radiation levels approaching $5 \mathrm{mrem} / \mathrm{hr}$, principally from beta decay of daughter products, may occur within the restricted area in such locations as inside furnaces or vented enclosures, or in areas adjacent to crucibles, castings, or the residues from casting. Ambient gamma ray levels within the facility seldom exceed $5 \mathrm{mrem} / \mathrm{hr}$ except in areas adjacent to source material. Wherever possible, gloves are used during handling procedures to reduce hand exposure. In 1992, the maximum individual occupational dose was an effective dose equivalent of approximately 2 rem. Average worker exposure was about $0.2 \mathrm{rem}$. The maximum and average effective dose equivalent received were about 40 percent and 4 percent, respectively, of the NRC occupational limit of 5 rem per year.

\subsubsection{Nonradiological impacts}

Public health and safety. The primary sources of nonradiological air emissions at NMI are two boilers, designated Units 1 and 2 . These boilers, which burn \#4 fuel oil, emit via their shared stack the following criteria pollutants: $\mathrm{SO}_{2}, \mathrm{NO}_{2}, \mathrm{PM}-10$, and $\mathrm{CO}$. The boiler stack is located on the southwestern edge of Building B (see Figure 2.1). In order for NMI to avoid 
being classified as a major source of emissions by the state of Massachusetts, the amount of \#4 fuel oil burned by the boilers is limited to $476,900 \mathrm{~L}(126,000$ gal) per month (short-term fuel usage) and 3,815,000 L (1,008,000 gal) per year (long-term usage) (DEP 1995). The criteria pollutant emission rates associated with these levels of fuel consumption are shown in Table 3.3.

Emissions of PM-10 also occur at the facility as a result of metal machining and processing operations. Because these emissions are much less than boiler emissions of PM-10 and have only a minor effect on air quality, they are not evaluated further.

Ambient air concentrations (at or beyond the site boundary) resulting from boiler emissions were estimated using the Industrial Source Complex-Version 2 (ISC2) air dispersion model (EPA 1992a). The ISC2 model is preferred by EPA for use in determining ambient air concentrations from point source emissions such as NMI's boiler stack (EPA 1995). Short-term emission rates in Table 3.3, calculated using the maximum monthly fuel usage rates, were used in ISC2 for periods of $24 \mathrm{hr}$ or less. Long-term emission rates in Table 3.3, calculated using the maximum annual fuel usage rates, were used in ISC2 for the annual time period. The stack parameters input into the ISC2 model are shown in Table 3.4.

Table 3.3. Maximum allowable emission $\operatorname{rates}^{a}$ of criteria pollutants for Nuclear Metals, Inc.

\begin{tabular}{lccccc}
\hline & $\begin{array}{c}\text { Maximum allowable short-term } \\
\text { emission rate }\end{array}$ & & \multicolumn{2}{c}{$\begin{array}{c}\text { Maximum allowable long-term } \\
\text { emission rate }^{a}\end{array}$} \\
\cline { 2 - 3 } \cline { 6 - 6 } Pollutant & tons/month & $\mathrm{g} / \mathrm{s}$ & & tons/y & $\mathrm{g} / \mathrm{s}$ \\
\hline $\mathrm{SO}_{2}^{b}$ & 9.5 & 3.6 & & 75.6 & 2.2 \\
$\mathrm{NO}_{2}^{b}$ & 3.0 & 1.1 & & 23.7 & 0.7 \\
$\mathrm{PM}^{b} 10^{b}$ & 0.6 & 0.2 & & 6.7 & 0.2 \\
$\mathrm{CO}^{b}$ & 0.4 & 0.1 & & 5.0 & 0.1 \\
\hline
\end{tabular}

${ }^{a}$ As approved by the Massachusetts Department of Environmental Protection (1995).

${ }^{b} \mathrm{Abbreviations:} \mathrm{SO}_{2}=$ sulfur dioxide; $\mathrm{NO}_{2}=$ nitrogen dioxide; $\mathrm{PM}-10=$ inhalable particulate matter with aerodynamic diameter of $10 \mu \mathrm{m}$ or less; $\mathrm{CO}=$ carbon monoxide. 
Table 3.4. Boiler stack parameters at Nuclear Metals, Inc. used as input for the ISC2 model

\begin{tabular}{ll}
\hline Parameter & \multicolumn{1}{c}{ Value } \\
\hline Stack height & $11.6 \mathrm{~m}(38.0 \mathrm{ft})$ \\
Effective stack diameter $^{a}$ & $1.1 \mathrm{~m}(3.6 \mathrm{ft})$ \\
Stack exit velocity & $1.5 \mathrm{~m} / \mathrm{s}(300 \mathrm{fpm})$ \\
Stack exit temperature & $519 \mathrm{~K}\left(475^{\circ} \mathrm{F}\right)$ \\
Maximum projected building width & $118 \mathrm{~m}(387 \mathrm{ft})$ \\
\hline
\end{tabular}

${ }^{a}$ The actual shape of the boiler stack is rectangular. The cross-sectional area of the stack is equal to $1.0 \mathrm{~m}^{2}\left(11.1 \mathrm{ft}^{2}\right)$. A circular stack with an equivalent cross-sectional area would have an effective stack diameter equal to $1.1 \mathrm{~m}(3.6 \mathrm{ft})$.

Onsite meteorological data covering a one year period were used in the modeling analysis. These onsite data include hourly measurements of wind speed and direction, and air temperature. The ISC2 model also requires hourly Pasquill-Gifford (PG) stability classes that are determined from a combination of meteorological parameters. It was not possible to determine the PG stability class from available onsite meteorological data by any EPA-approved method (EPA 1987). To overcome this lack of data, three meteorological scenarios were run to determine maximum ambient concentrations. The first scenario assumed PG stability class D (neutral stability) for all hours during the year. The second scenario assumed PG stability class D during the daytime [defined as the hours occurring $1 \mathrm{hr}$ after sunrise to $1 \mathrm{hr}$ before sunset (EPA 1987)] and PG stability class E (slightly stable atmospheric conditions) at night. The third scenario assumed PG stability class D during the daytime and PG stability class F (stable atmospheric conditions) at night. Use of other stability classes would result in lower concentrations as determined in a preliminary assessment using the SCREEN2 model (EPA 1992b). 
Receptors were located in a rectangular grid extending $1,000 \mathrm{~m}(3,300 \mathrm{ft})$ from the facility in all directions, spaced $100 \mathrm{~m} \mathrm{(330} \mathrm{ft)}$ apart in both the north-south and east-west directions. Receptors were also located along the facility boundary. Because the stack is only

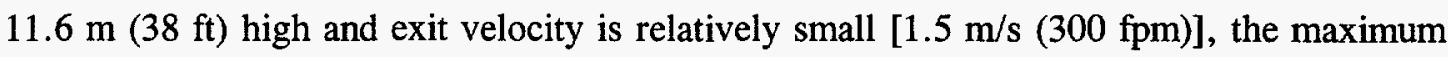
increases in ambient air concentrations associated with the operation of the boilers would occur within $1,000 \mathrm{~m}(3,300 \mathrm{ft})$ of the facility.

Building wake and terrain effects were incorporated into the model. Because the terrain around the NMI facility is classified as rolling (terrain elevations are below the height of the stack), the use of the ISC2 model is appropriate (EPA 1995).

The results of the modeling analysis are shown in Table 3.5. The maximum modeled concentrations from the three meteorological scenarios were added to background concentrations (maximum ambient concentrations near the site measured by the state of Massachusetts) to obtain total predicted concentrations. Total predicted concentrations were compared to the NAAQS in order to gauge impacts on air quality. Note that because the boilers have been operating since 1958, comparisons are not required with Prevention of Significant Deterioration (PSD) increments, which are standards that protect air quality against degradation from emissions sources that began operating on or after 1977.

The results of the analysis show that maximum 3-hr and 24-hr average $\mathrm{SO}_{2}$ concentrations are about twice their respective NAAQS. These maximum concentrations occur at a receptor located at the southern boundary of the site. The meteorological scenario associated with the maximum 3-hr concentration is PG stability class D during the daytime and PG stability class $\mathrm{F}$ at night, and the meteorological scenario associated with maximum 24-hr concentration is PG stability class D for all hours.

Because modeling results for $\mathrm{SO}_{2}$ indicate that the potential exists for exceeding the short-term NAAQS, boiler emissions may have a considerable impact on the local air quality with regard to $\mathrm{SO}_{2}$. For all other criteria pollutants, maximum concentrations are within the NAAQS, and impacts to local air quality associated with these pollutants would be minor. NMI is prepared to undertake mitigative action to prevent potential exceedances of the shortterm $\mathrm{SO}_{2} \mathrm{NAAQS}$ during normal operations (see Section 3.1.5). 
Table 3.5. Maximum predicted concentrations of criteria pollutants from boiler emissions at Nuclear Metals, Inc. compared to the National Ambient Air Quality Standards (NAAQS)

\begin{tabular}{|c|c|c|c|c|c|c|}
\hline \multirow[b]{2}{*}{ Pollutant } & \multirow{2}{*}{$\begin{array}{l}\text { Averaging } \\
\text { period }\end{array}$} & \multicolumn{3}{|c|}{ Maximum concentration $\left(\mu \mathrm{g} / \mathrm{m}^{3}\right)$} & \multirow[b]{2}{*}{ NAAQS } & \multirow{2}{*}{$\begin{array}{c}\text { Percent of } \\
\text { NAAQS }\end{array}$} \\
\hline & & Modeled $^{a}$ & Background $^{b}$ & Total $^{c}$ & & \\
\hline \multirow[t]{3}{*}{$\mathrm{SO}_{2}{ }^{d}$} & 3-hr & 2,426 & 181 & 2,607 & 1,300 & 201 \\
\hline & 24-hr & 796 & 92 & 888 & 365 & 243 \\
\hline & annual & 43 & 16 & 59 & 80 & 73 \\
\hline $\mathrm{NO}_{2}{ }^{d}$ & annual & 13 & 64 & 77 & 100 & 77 \\
\hline \multirow[t]{2}{*}{$\mathrm{PM}-10^{d}$} & $24-\mathrm{hr}$ & 42 & 62 & 104 & 150 & 70 \\
\hline & annual & 4 & 16 & 20 & 50 & 40 \\
\hline \multirow[t]{2}{*}{$\mathrm{CO}^{d}$} & $1-\mathrm{hr}$ & 157 & 9,085 & 9,242 & 40,000 & 23 \\
\hline & $8-\mathrm{hr}$ & 49 & 5,750 & 5,799 & 10,000 & $\dot{58}$ \\
\hline
\end{tabular}

${ }^{a}$ Maximum modeled concentrations in the ambient air predicted using the ISC2 model (EPA 1992a).

${ }^{b}$ Maximum background concentrations measured at nearby monitors (see Table 3.1).

${ }^{c}$ Total concentrations are the sum of modeled and background concentrations.

${ }^{d}$ Abbreviations: $\mathrm{SO}_{2}=$ sulfur dioxide; $\mathrm{NO}_{2}=$ nitrogen dioxide; $\mathrm{PM}-10=$ inhalable particulate matter with 
Worker health and safety. Because of the type of operations at NMI, there are limited opportunities for workers to be exposed to nonradiological hazardous chemicals. The most likely situations would occur during pickling, etching, and metal cleaning. Parts may be cleaned by immersion in acids or contact with organic solvents or detergents. Acids may also be employed to remove jacketing or metal cladding materials. Operations that are likely to generate appreciable airborne particulate matter, such as acid pickling or etching, are vented to the atmosphere. Immersion of parts in organic solvents or detergents does not generate airborne particulate matter. The air cleaning equipment needed to restrict the exposure to airborne radioactive materials also functions to minimize inhalation exposures to hazardous chemicals. Wherever possible, workers involved in cleaning processes wear protective gloves. The Hydromet process also uses several types of acids but, for the most part, this process is enclosed, precluding workers from appreciable exposure to fumes.

\subsubsection{Accidental Atmospheric Releases}

The analysis in this section estimates the potential quantities of uranium and nonradiological materials that might be released to the atmosphere in the unlikely event of a major fire at the NMI facility. From those quantities, the amount that could be inhaled by an offsite receptor is then estimated. The analysis is a "screening level" assessment and is not intended to be a substitute for a more detailed safety analysis or a probabilistic risk assessment. This section evaluates the source term data, the atmospheric dispersion of materials, the inhalation exposure pathway for a nearby exposed individual, and the health effects or health risks of such exposure.

\subsubsection{Uranium inventories}

As noted earlier, two types of radioactive material could be present at NMI: natural uranium and depleted uranium. These materials are considered separately in this analysis. As shown in Figure 2.1, the uranium processing areas at NMI are located in Buildings C, D, and E. The historical maximum quantities of depleted uranium at various locations throughout 
Buildings C, D, and $\mathrm{E}$ are shown in Table 3.6. Because the processes at NMI primarily involve metal forming, fabrication, and machining, the principal inventory of uranium metal is in the form of large solid blocks, as opposed to liquids or chips/fines. It is important to note that the quantities in Table 3.6 represent maximum quantities at the specified locations; therefore, to sum all such quantities within a building or among buildings would be somewhat misleading with respect to the total inventory at NMI, because it is unlikely that all of the tabulated maximum quantities would be simultaneously present at the specified locations. Although the quantity of depleted uranium requested in the license renewal application is substantially larger than the sum of all inventories presented in Table $3.6[5,000,000 \mathrm{~kg}$ vs. approximately $1,700,000 \mathrm{~kg}(11,000,000 \mathrm{lb}$ vs. 3,800,000 lb)], NMI has committed to limit the inventory of depleted uranium in any one of its buildings to less than $454,000 \mathrm{~kg}$ $(1,000,000 \mathrm{lb}$ ) (Andersen 1996). While the quantities in Table 3.6 are used initially in the accident analysis to provide historical perspective, the $454,000-\mathrm{kg}(1,000,000-\mathrm{lb})$ limit that is analyzed subsequently represents the upper bound for potential impacts in the future.

No detailed breakdown of the location and inventories of natural uranium at NMI is available. For the accident analysis below, the entire $100,000-\mathrm{kg}(220,000-\mathrm{lb})$ inventory of natural uranium, as requested in the license renewal application, is assumed to be involved in the accident.

\subsubsection{Accident scenarios}

In 1987, NRC conducted a regulatory analysis documented in NUREG-1140 (McGuire 1988) of its fuel cycle and other radioactive material licensees to identify the classes of licensees that could have accidents with the potential to result in radiation doses to the public exceeding protective action guides established by EPA. In that regulatory analysis, the plausibility of exceeding EPA's protective action guides was considered from two points of view: (1) the accident history of fuel cycle and byproduct material licensees, and (2) theoretical calculations of the releases and offsite doses of credible accidents. Protective action guides are expressed in terms of projected doses to individuals in the population which 
Table 3.6. Maximum quantities of depleted uranium historically located in process-specific areas at Nuclear Metals, Inc. (NMI)

\begin{tabular}{|c|c|c|c|c|}
\hline \multirow[b]{2}{*}{ Process area } & \multicolumn{4}{|c|}{ Quantity in specified form $\left(\mathrm{kg}^{a}\right)$} \\
\hline & Solids & Chips, etc. & Liquids & Total \\
\hline & \multicolumn{2}{|c|}{ Building C } & & \\
\hline Machine Shop & 34,020 & 550 & 0 & 34,570 \\
\hline Foundry & 113,650 & 2,820 & 0 & 116,470 \\
\hline Extrusion & 85,050 & 0 & 0 & 85,050 \\
\hline Packaging & 143,700 & 0 & 0 & 143,700 \\
\hline $\mathrm{CAF}$ & 11,340 & 0 & 0 & 11,340 \\
\hline Totals for Building $\mathrm{C}$ & 387,760 & 3,370 & 0 & 391,130 \\
\hline \multicolumn{5}{|c|}{ Building D } \\
\hline Fabrication & 66,680 & 181 & 0 & 66,861 \\
\hline Acid Area & 26,090 & 0 & 23 & 26,113 \\
\hline $\mathrm{CNC}$ & 86,070 & 680 & 0 & 86,750 \\
\hline Quality Control & 71,450 & 0 & 0 & 71,450 \\
\hline Totals for Building D & 250,290 & 861 & 23 & 251,174 \\
\hline \multicolumn{5}{|c|}{ Building $\mathbf{E}$} \\
\hline Quality Control & 179,970 & 0 & 0 & 179,970 \\
\hline 1250 Press & 9,980 & 0 & 0 & 9,980 \\
\hline Resource Recovery & 0 & 90 & 15 & 105 \\
\hline Hydromet Chips & 0 & 460 & 460 & 920 \\
\hline Hydromet $\mathrm{UF}_{4}$ & 0 & 45,360 & 0 & 45,360 \\
\hline Shear & 99,790 & 0 & 0 & 99,790 \\
\hline Waste Process & 0 & 1,140 & 0 & 1,140 \\
\hline Charge Preparation & 752,970 & 0 & 0 & 752,970 \\
\hline Totals for Building $E$ & $1,042,710$ & 47,050 & 475 & $1,090,235$ \\
\hline
\end{tabular}

$a_{1} \mathrm{~kg}=2.2 \mathrm{lb}$.

Source: Quantity data supplied by NMI. 
warrant taking protective action. EPA recommends that protective actions should be considered if projected total effective dose equivalents are in the range of 1 to 5 rems.

The regulatory analysis in NUREG-1140 evaluated many plausible accident scenarios for various types of licensed facilities. The most significant accidents were determined to be $\mathrm{UF}_{6}$ releases, fires, and criticality accidents. The fraction of radioactive material released in fires was considered to be larger than that released in other types of accidents. The regulatory analysis concluded that for facilities such as NMI, accidental releases from fires should be used to determine whether protective action guides would be exceeded in the event of an accident. Because $\mathrm{UF}_{6}$ releases and criticalities are not credible events at NMI, this analysis focuses on fires at the NMI facility.

\subsubsection{Fire-related assumptions}

Buildings $\mathrm{C}, \mathrm{D}$, and $\mathrm{E}$, which house the uranium processing areas at NMI, are separated from each other by fire walls. Door openings through these walls are protected by fusible-link operated fire-rated doors and all pipe penetrations between the buildings are sealed. Due to the presence of the fire walls, the analysis assumes that a fire originating in one of the buildings would not spread to the others. Therefore, the uranium exposed to a fire would be limited to the inventory present in the burning building.

Skylights that are present in each of the buildings also affect the analysis. The skylights are fusible-link operated vents that open in the event of heat build-up from a fire. They are assumed to provide a direct pathway-without constraint-for the release of radioactive material from a building during a fire. The released material would thus bypass the installed ventilation exhaust and filtration systems.

No credit is taken for automatic fire suppression by the sprinkler systems installed in the facility. Only manual fire fighting efforts are considered. In discussions with local fire officials, it was determined that 2 hours would represent the maximum duration under which a large fire could burn before it would be manually extinguished (Department Chief Robinson, Concord Fire Department, Concord, Mass., personal communication with 
R. T. Wimbrow and G. P. Zimmerman, Oak Ridge National Laboratory, Oak Ridge, Tenn., May 11, 1995). Two hours is therefore used as the maximum fire duration.

While a detailed survey was not undertaken to identify the amount and location of combustible materials present at NMI, such materials were observed during a walk-through tour of the facility. For the analysis, a "worst case" simplifying assumption is made that sufficient combustible materials would be present to sustain a lengthy, hot fire that is capable of oxidizing uranium. This assumption forms an upper bound for Buildings C and D where the combustible loading was observed to be low. The assumption is more representative for Building $\mathrm{E}$ where heavy concentrations of combustible materials were noted. An emergency diesel generator and its 1,040-L (275-gal) fuel oil storage tank located in Building E are appreciable potential sources of combustion. Numerous cardboard boxes were stored in the building's mezzanine area, and scrap lumber and cardboard were present in the waste packaging area. Other combustible materials were distributed throughout the building in smaller quantities. Although the uranium in Building $\mathrm{E}$ was not in the immediate vicinity of the concentrated combustible materials, there are no internal barriers in the building that are capable of preventing the spread of fire and heat. It is therefore possible that all of the combustible materials could become involved, resulting in a fire approaching the assumed severity and duration.

\subsubsection{Accident analysis}

In NUREG-1140, doses from airborne releases were calculated by (1) assuming specified release fractions for the radioactive materials involved in the fire, (2) employing an atmospheric dispersion model, and (3) calculating doses to a downwind receptor from three pathways: inhalation (from radioactive particulate matter suspended in the air), external exposure from cloudshine (from radioactive particulate matter suspended in the air), and external exposure from groundshine (from radioactive particulate matter deposited on the ground). For uranium, NUREG-1140 found that the highest doses come from the inhalation pathway, and doses from the other pathways could be reasonably ignored. The principal 
assumptions from the NUREG-1140 regulatory analysis are presented in Appendix B and are summarized below.

In the event of an accidental release of uranium from a fire, downwind atmospheric dispersion and subsequent inhalation would be the exposure pathway of interest. The atmospheric dispersion model used in this analysis is a standard Gaussian plume model. Doses were calculated with two sets of meteorological conditions: stability class $F$ with $1 \mathrm{~m} / \mathrm{s}$ (2 mph) wind speed and stability class D with $4.5 \mathrm{~m} / \mathrm{s}(10 \mathrm{mph})$ wind speed. The $F, 1 \mathrm{~m} / \mathrm{s}$ ( $2 \mathrm{mph}$ ) condition represents an infrequent, but extremely adverse meteorological condition in which near maximum doses would be delivered to an exposed individual. This condition can be interpreted as a "worst case" meteorological condition. The $\mathrm{D}, 4.5 \mathrm{~m} / \mathrm{s}(10 \mathrm{mph})$ condition represents a more typical meteorological condition and is included here to illustrate the dose that would be expected under more likely conditions than the worst case.

Following the guidance in NUREG-1140, the initiating accident and the subsequent release of radioactive material is assumed to occur at ground level. A deposition velocity of $1 \mathrm{~cm} / \mathrm{s}$ is included in the atmospheric dispersion model. Concentrations along the plume centerline downwind of the accidental release would represent maxima, in that individuals located to either side of the plume centerline would receive lesser exposures due to cross-wind dispersion (dilution).

Inhalation exposures were calculated for an individual standing in an open field, downwind from the accident, and located on the plume centerline. The individual's breathing rate was taken as $2.66 \times 10^{-4} \mathrm{~m}^{3} / \mathrm{s}$ [about $8,390 \mathrm{~m}^{3} / \mathrm{yr}$, a typical rate for an adult assuming a mixture of sleep, rest, and light activity (ICRP 1994)]. Actual exposures to people would be less than those given in this analysis because obstacles to wind flow (e.g., trees, buildings, and hills) would cause the plume to broaden and to mix the contaminants with uncontaminated air. In addition, exposures to people located downwind inside buildings would be smaller than those given in this analysis because of the buildings' resistance to infiltration, which would provide additional protection from airborne hazards.

The exposed individual was assumed to breathe contaminated air throughout the duration of the fire and the passage of the plume, a very conservative assumption. In accordance with NUREG-1140, the exposed individual was assumed to be at a location $100 \mathrm{~m}$ (330 ft) 
downwind of the accident. According to NUREG-1140, limiting the examination of exposure by inhalation to distances at or greater than $100 \mathrm{~m}$ (330 ft) downwind implies that a person standing in dense smoke or irritating fumes on the plume centerline at a point closer than $100 \mathrm{~m}(330 \mathrm{ft})$ from the point of release would move out of the smoke before the release ends.

The following equation was used to relate inhalation exposure to the quantity of radioactive material released and dispersed downwind toward the exposed individual:

$$
q_{i}=B \times \chi / Q \times q_{R}
$$

(Equation 1)

where,

$q_{i}$ is the inhaled mass of uranium (in $\mathrm{kg}$ ),

$B$ is the breathing rate of the exposed individual (in $\mathrm{m}^{3} / \mathrm{s}$ ),

$\chi / Q$ is the concentration in air at a particular downwind location per release rate of material at the point of release (in $\mathrm{kg} / \mathrm{m}^{3}$ per $\mathrm{kg} / \mathrm{s}$, or $\mathrm{s} / \mathrm{m}^{3}$ ), and

$q_{R}$ is the mass of radioactive material released (in $\mathrm{kg}$ ).

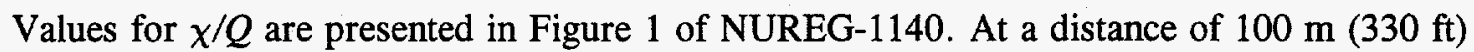
from the hypothetical accident (a distance recommended for analysis in NUREG-1140), the values for $\chi / Q$ are $3.3 \times 10^{-3} \mathrm{~s} / \mathrm{m}^{3}$ for $\mathrm{F}, 1 \mathrm{~m} / \mathrm{s}(2 \mathrm{mph})$ meteorological conditions ("worst case") and $4.4 \times 10^{-4} \mathrm{~s} / \mathrm{m}^{3}$ for D, $4.5 \mathrm{~m} / \mathrm{s}(10 \mathrm{mph})$ conditions. In other words, Equation 1 yields inhaled quantities for the F, $1 \mathrm{~m} / \mathrm{s}(2 \mathrm{mph})$ meteorology that are a factor of 7.5 higher than for the $\mathrm{D}, 4.5 \mathrm{~m} / \mathrm{s}(10 \mathrm{mph})$ meteorology.

Whereas the above equation relates the inhaled portion of radioactive materials to the quantity released in an accident, consideration must also be given to the quantity of radioactive material actually involved in the accident. Previous studies of uranium in fires (Carter and Stewart 1970; Elder and Tinkle 1980; Mishima et al. 1985) have observed that inhalable quantities could be produced, but with the following limitations:

- only the uranium oxidized by the fire can become airborne, 
- not all of the oxidized uranium will become airborne, and

- not all of the airborne material is respirable (i.e., less than $10 \mu \mathrm{m}$ in aerodynamic diameter).

The equation that includes these observations may be expressed as:

$$
q_{R}=M_{T} \times D R \times R F \times r_{f}
$$

(Equation 2)

where,

$M_{T}$ is the total mass of radioactive material involved in the accident (in $\mathrm{kg}$ ), also called the "mass-at-risk" in some analyses,

$D R$ is a dimensionless "damage ratio" that represents the mass fraction of the mass-at-risk actually impacted by the accident-generated conditions,

$R F$ is the dimensionless release fraction (mass fraction) of the material damaged in the accident that becomes airborne, and

$r_{f}$ is the dimensionless respirable fraction (mass fraction) of the airborne material.

In the uranium fire studies mentioned previously, temperatures of $500^{\circ} \mathrm{C}\left(930^{\circ} \mathrm{F}\right)$ in excess of 30 minutes were required to initiate oxidation of uranium metal. In experiments at up to $1,000^{\circ} \mathrm{C}\left(1,830^{\circ} \mathrm{F}\right)$, as much as 85 percent oxidation of the uranium metal was observed after periods of 16 to $20 \mathrm{hr}$. In one set of tests involving solid uranium bars (Elder and Tinkle 1980), a 4-hr fire produced an average of 44 percent oxidation among three test items.

Consequently, for the purposes of this analysis, it was assumed that 50 percent of the uranium involved in the fire at NMI would be oxidized; that is, the value of the damage ratio $(D R)$ was taken as 0.5 . This value is acknowledged to be a conservative (or pessimistic) assumption for use at the NMI facilities, but it is nevertheless used in the absence of better information.

Determination of values for $R F$ and $r_{f}$ has been the subject of many studies (see Mishima et al. 1994 for a comprehensive summary of uranium experiments for the U.S. Army). A recent publication by the U.S. Department of Energy (DOE) (see Mishima and Pinkston 1994) 
contains recommended $R F$ and $r_{f}$ values for use in uranium and plutonium accident analyses. Two sets of values are offered in the DOE report: one for use in bounding calculations and one for the median of available experimental data. The DOE median values for fires involving solid uranium are an $R F$ of 0.0001 and an $r_{f}$ of 1.0 . The bounding values are an $R F$ of 0.001 and an $r_{f}$ of 1.0; hence, the mathematical product of the bounding values (i.e., $R F \times r_{f}$ ) is 10 times higher than for the median values.

Combining Equations 1 and 2 produces the desired relationship between "mass-at-risk" and inhaled quantities of uranium:

$$
q_{i}=M_{T} \times D R \times R F \times r_{f} \times B \times \chi / Q
$$

Table 3.7 shows the germane input values for the above equation.

Equation 3 was applied to the quantities of both natural and depleted uranium at NMI.

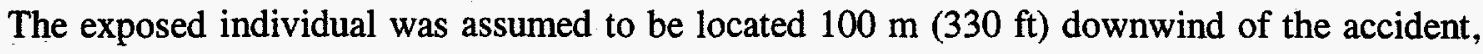
and F, $1 \mathrm{~m} / \mathrm{s}(2 \mathrm{mph})$ "worst case" meteorological conditions were assumed to apply. Table 3.8 shows the quantities of depleted uranium that would be inhaled by the exposed

Table 3.7. Values for input parameters used in the accident analysis for Nuclear Metals, Inc.

\begin{tabular}{ll}
\hline \multicolumn{1}{c}{ Parameter } & \multicolumn{1}{c}{ Value } \\
\hline $\begin{array}{c}\text { Total quantity of uranium } \\
\text { involved in fire, } M_{T}\end{array}$ & See Table 3.6 \\
Damage ratio, $D R$ & 0.5, dimensionless (fraction oxidized in fire) \\
Release fraction, $R F$ & 0.0001 , dimensionless (median value) \\
Respirable fraction, $r_{f}$ & 1.0, dimensionless (upper bound) \\
Breathing rate, $B$ & $2.66 \times 10^{-4} \mathrm{~m}^{3} / \mathrm{s}$ \\
Atmospheric dispersion term, $\chi / Q$ & $3.3 \times 10^{-3} \mathrm{~s} / \mathrm{m}^{3}$ for F stability and \\
$\quad$ (for receptor located $100 \mathrm{~m}$ & $1 \mathrm{~m} / \mathrm{s} \mathrm{wind} \mathrm{speed;}$ \\
downwind) & $4.4 \times 10^{-4} \mathrm{~s} / \mathrm{m}^{3}$ for D stability and \\
& $4.5 \mathrm{~m} / \mathrm{s} \mathrm{wind} \mathrm{speed}$ \\
\hline
\end{tabular}


Table 3.8. Quantities of depleted uranium potentially inhaled by an exposed individual in the event of a severe fire at Nuclear Metals, Inc. facilities (based on historical quantities)

\begin{tabular}{|c|c|c|c|c|}
\hline \multirow[b]{2}{*}{ Process area } & \multicolumn{4}{|c|}{ Inhaled quantity from specified source/form (mg) } \\
\hline & Solids & Chips, etc. & Liquids & Total \\
\hline \multicolumn{5}{|c|}{ Building C } \\
\hline Machine Shop & 1.5 & 0.1 & 0.0 & 1.6 \\
\hline Foundry & 5.0 & 0.1 & 0.0 & 5.1 \\
\hline Extrusion & 3.7 & 0.0 & 0.0 & 3.7 \\
\hline Packaging & 6.3 & 0.0 & 0.0 & 6.3 \\
\hline CAF & 0.5 & 0.0 & 0.0 & 0.5 \\
\hline Totals for Building $\mathrm{C}$ & 17.0 & 0.2 & 0.0 & 17.2 \\
\hline \multicolumn{5}{|c|}{ Building D } \\
\hline Fabrication & 2.9 & 0.0 & 0.0 & 2.9 \\
\hline Acid Area & 1.2 & 0.0 & 0.0 & 1.2 \\
\hline $\mathrm{CNC}$ & 3.8 & 0.0 & 0.0 & 3.8 \\
\hline Quality Control & 3.1 & 0.0 & 0.0 & 3.1 \\
\hline Totals for Building D & 11.0 & 0.0 & 0.0 & 11.0 \\
\hline \multicolumn{5}{|c|}{ Building. E } \\
\hline Quality Control & 7.9 & 0.0 & 0.0 & 7.9 \\
\hline 1250 Press & 0.4 & 0.0 & 0.0 & 0.4 \\
\hline Resource Recovery & 0.0 & 0.0 & 0.0 & 0.0 \\
\hline Hydromet Chips & 0.0 & 0.0 & 0.0 & 0.0 \\
\hline Hydromet $\mathrm{UF}_{4}$ & 0.0 & 2.0 & 0.0 & 2.0 \\
\hline Shear & 4.4 & 0.0 & 0.0 & 4.4 \\
\hline Waste Process & 0.0 & 0.1 & 0.0 & 0.1 \\
\hline Charge Preparation & 33.1 & 0.0 & 0.0 & 33.1 \\
\hline Totals for Building $\mathrm{E}$ & 45.8 & 2.1 & 0.0 & 47.9 \\
\hline
\end{tabular}

Note: The exposed individual is assumed to be on the plume centerline, $100 \mathrm{~m}(330 \mathrm{ft})$ downwind from the accident. A "worst case" meteorological condition of $F$ stability with a wind speed of $1 \mathrm{~m} / \mathrm{s}$ (2 mph) is assumed. For D stability with a wind speed of $4.5 \mathrm{~m} / \mathrm{s}(10 \mathrm{mph})$, the inhaled quantities would be a factor of 7.5 smaller than the tabulated values. 
individual using the maximum quantities of depleted uranium historically located in process areas at NMI (i.e., from Table 3.6) under "worst case" meteorological conditions. For the limiting value agreed to by NMI of $454,000 \mathrm{~kg}(1,000,000 \mathrm{lb})$ of depleted uranium in any one building, Equation 3 yields an inhaled quantity of $20 \mathrm{mg}$ at $100 \mathrm{~m}(330 \mathrm{ft})$.

No detailed breakdown of the location and inventories of natural uranium at NMI is available. Application of Equation 3 to the entire $100,000-\mathrm{kg}(220,000-\mathrm{lb})$ inventory of natural uranium requested in the license renewal application yields an inhaled quantity of $4.4 \mathrm{mg}$ at $100 \mathrm{~m}(330 \mathrm{ft})$.

Inhaled uranium can produce both a radiological dose (see Section 3.1.2.5) and health impacts due to the chemical toxicity of uranium (see Section 3.1.2.6). Because the assumptions used for the accident and exposure calculations for this assessment are consistently conservative, the results should be viewed as upper bound estimates.

\subsubsection{Radiological impacts of uranium}

For application of NUREG-1140 (McGuire 1988) to fuel cycle and byproduct material licensees, the lower end of EPA's range of protective action guides (i.e., 1 rem) (EPA 1980) is to be used in conjunction with calculations of releases and offsite radiation doses due to severe accidents, such as a major facility fire. The regulatory analysis in NUREG-1140 uses the committed effective dose equivalent in its calculations. The committed effective dose equivalent is the sum of the 50-year dose equivalent commitment to each body organ multiplied by a weighting factor for each organ as given in ICRP Publication 26. For the inhalation pathway, dose conversion factors from ICRP Publication 30 were used (ICRP 1979 and 1980). The clearance class for the uranium oxide was taken as Class $Y$ (year) due to the expectation that insoluble oxides would be generated in uranium fires and internal exposure would therefore occur over several years (Mishima et al. 1985).

The committed effective dose equivalent can be related to the inhaled mass of uranium by the following equation:

$$
H=q_{i} \times \alpha_{s} \times D C F
$$

(Equation 4) 
where,

$H$ is the committed effective dose equivalent from inhalation (in rems),

$q_{i}$ is the inhaled mass of uranium (in $\mathrm{kg}$ ),

$\alpha_{s}$ is the specific activity of the uranium (in $\mu \mathrm{Ci} / \mathrm{kg}$ ), and

$D C F$ is the dose conversion factor (in $\mathrm{rem} / \mu \mathrm{Ci}$ inhaled).

The specific activity relates the activity of the uranium (in $\mu \mathrm{Ci}$ ) and its mass (in $\mathrm{kg}$ ). The specific activities of depleted and natural uranium are $370 \mu \mathrm{Ci} / \mathrm{kg}$ and $700 \mu \mathrm{Ci} / \mathrm{kg}$, respectively. The dose conversion factors (for the 50-year committed effective dose equivalent from the inhalation pathway only) for depleted and natural uranium are $120 \mathrm{rem} / \mu \mathrm{Ci}$ and $124 \mathrm{rem} / \mu \mathrm{Ci}$, respectively (McGuire 1988).

Table 3.9 shows the doses to a nearby downwind individual that would result from a fire involving the historical quantities of depleted uranium in Table 3.6 and the resulting inhaled quantities in Table 3.8. For the limiting value agreed to by NMI of 454,000 $\mathrm{kg}(1,000,000 \mathrm{lb})$ of depleted uranium in any one building, Equations 3 and 4 yield a committed effective dose equivalent of 0.89 rems at $100 \mathrm{~m}$ (330 ft). This value is less than the EPA-recommended lower limit for consideration of protective actions (i.e., a dose of $1 \mathrm{rem}$ ). Therefore, NMI's commitment to limit the depleted uranium inventory ensures that radiological impacts, in the unlikely event of a severe fire, would not be major.

As discussed earlier, these doses are for a "worst case" meteorological condition [i.e., F stability with $1 \mathrm{~m} / \mathrm{s}(2 \mathrm{mph})$ wind speed]. For a more likely meteorological condition - namely D stability with $4.5 \mathrm{~m} / \mathrm{s}(10 \mathrm{mph})$ wind speed-the doses would be smaller by a factor of 7.5 . Consideration of the $D, 4.5 \mathrm{~m} / \mathrm{s}(10 \mathrm{mph})$ condition would result in none of the doses exceeding $1 \mathrm{rem}$, even for the historical inventory (Table 3.6).

No detailed breakdown of the location and inventories of natural uranium at NMI is available. Application of Equations 3 and 4 to the entire 100,000-kg (220,000-lb) inventory of natural uranium requested in the license renewal application yields a committed effective dose equivalent of $0.4 \mathrm{rem}$ at $100 \mathrm{~m}$ (330 ft) under F stability with $1 \mathrm{~m} / \mathrm{s}(2 \mathrm{mph})$ wind speed. This dose is below the EPA-recommended limit of 1 rem that would trigger consideration of 
Table 3.9. Doses from depleted uranium to a nearby exposed individual in the event of a severe fire at Nuclear Metals, Inc. facilities (based on historical quantities)

\begin{tabular}{|c|c|c|c|c|}
\hline \multirow[b]{2}{*}{ Process area } & \multicolumn{4}{|c|}{ Dose from specified source/form (rems) } \\
\hline & Solids & Chips, etc. & Liquids & Total \\
\hline \multicolumn{5}{|c|}{ Building $\mathrm{C}$} \\
\hline Machine Shop & 0.1 & 0.0 & 0.0 & 0.1 \\
\hline Foundry & 0.2 & 0.0 & 0.0 & 0.2 \\
\hline Extrusion & 0.2 & 0.0 & 0.0 & 0.2 \\
\hline Packaging & 0.3 & 0.0 & 0.0 & 0.3 \\
\hline $\mathrm{CAF}$ & 0.0 & 0.0 & 0.0 & 0.0 \\
\hline Totals for Building $\mathrm{C}$ & 0.8 & 0.0 & 0.0 & 0.8 \\
\hline \multicolumn{5}{|c|}{ Building D } \\
\hline Fabrication & 0.1 & 0.0 & 0.0 & 0.1 \\
\hline Acid Area & 0.1 & 0.0 & 0.0 & 0.1 \\
\hline $\mathrm{CNC}$ & 0.2 & 0.0 & 0.0 & 0.2 \\
\hline Quality Control & 0.1 & 0.0 & 0.0 & 0.1 \\
\hline Totals for Building D & 0.5 & 0.0 & 0.0 & 0.5 \\
\hline \multicolumn{5}{|c|}{ Building $\mathbf{E}$} \\
\hline Quality Control & 0.3 & 0.0 & 0.0 & 0.3 \\
\hline 1250 Press & 0.0 & 0.0 & 0.0 & 0.0 \\
\hline Resource Recovery & 0.0 & 0.0 & 0.0 & 0.0 \\
\hline Hydromet Chips & 0.0 & 0.0 & 0.0 & 0.0 \\
\hline Hydromet $\mathrm{UF}_{4}$ & 0.0 & 0.1 & 0.0 & 0.1 \\
\hline Shear & 0.2 & 0.0 & 0.0 & 0.2 \\
\hline Waste Process & 0.0 & 0.0 & 0.0 & 0.0 \\
\hline Charge Preparation & 1.5 & 0.0 & 0.0 & 1.5 \\
\hline Totals for Building $\mathrm{E}$ & 2.0 & 0.1 & 0.0 & 2.1 \\
\hline
\end{tabular}

Note: The exposed individual is assumed to be on the plume centerline, $100 \mathrm{~m} \mathrm{(330} \mathrm{ft)}$ downwind from the accident. A "worst case" meteorological condition of F stability with a wind speed of $1 \mathrm{~m} / \mathrm{s}(2 \mathrm{mph})$ is assumed. For D stability with a wind speed of $4.5 \mathrm{~m} / \mathrm{s}$ $(10 \mathrm{mph})$, the inhaled quantities would be a factor of 7.5 smaller than the tabulated values. 
protective actions. Therefore, radiological impacts resulting from exposure to natural uranium during a severe fire would not be major.

\subsubsection{Chemical toxicity of uranium}

This section discusses the potential impacts due to the chemical toxicity of uranium that would be released during the accidental fire scenario discussed above. Uranium is toxic to a number of tissues and organs including the lungs, liver, cardiovascular system, central nervous system, and reproductive system, but its chemical toxicity is greatest for the kidneys (Hodge et al. 1973). Because of the multiple nature of the hazards from uranium, NRC developed criteria for establishing whether a licensed facility would be required to establish and maintain an emergency plan for significant accidental releases (54 FR 14051, April 7, 1989). In addition to the criterion for the radiation dose, a criterion was adopted for chemical toxicity based on an accident which could theoretically deliver a soluble uranium intake exceeding $2 \mathrm{mg}$ to a member of the public.

For this analysis, it was assumed that 5 percent of the uranium that was lost from the inventory during the fire arrived at the point of inhalation in a soluble form (Mishima et al. 1985). Applying a factor of 0.05 to the quantities inhaled in an accident involving the $454,000-\mathrm{kg}(1,000,000-\mathrm{lb})$ limit of depleted uranium agreed to by NMI results in an inhalation of about $1 \mathrm{mg}$ of soluble uranium. This value is less than the $2-\mathrm{mg}$ level set by NRC, which is considered to be an intake from which no clinical evidence of chemical injury would be expected. It is also below the Emergency Response Planning Guideline 2 (ERPG-2) level of $10 \mathrm{mg}$ established by the American Industrial Hygiene Association as the maximum quantity of soluble uranium to which nearly all individuals can be exposed for up to $1 \mathrm{hr}$ without developing irreversible health effects. For the natural uranium inventory requested by NMI, the corresponding results indicate that only about $0.2 \mathrm{mg}$ of soluble uranium would be inhaled. Therefore, NMI's commitment to limit the depleted uranium inventory and their requested level for the natural uranium inventory ensure that no major impacts would result from the chemical toxicity of uranium released in the unlikely event of a severe fire. 


\subsubsection{Nonradiological materials}

This section discusses the potential impacts resulting from NMI's use of several acids: hydrochloric $(\mathrm{HCl})$, hydrofluoric $(\mathrm{HF})$, fluoroboric $\left(\mathrm{HBF}_{4}\right)$, and sulfuric $\left(\mathrm{H}_{2} \mathrm{SO}_{4}\right)$. Table 3.10 shows the volumes of acids present at NMI and the corresponding quantities of the hazardous substances contained within the acid solutions. Both $\mathrm{HCl}$ and $\mathrm{HF}$ are present in 415-L (110-gal) tanks. The $\mathrm{HCl}$ is a 20 percent $(2.4 \mathrm{~N})$ solution and the $\mathrm{HF}$ is a 50 percent $(10.9 \mathrm{~N})$ solution.

Large quantities of sulfuric acid are used or stored primarily in two locations at NMI: in Building $\mathrm{E}$ (near the resource recovery area) and in the receiving area in the B-4 building. In Building $\mathrm{E}$, a 5 percent $(1.8 \mathrm{~N})$ solution of $\mathrm{H}_{2} \mathrm{SO}_{4}$ is contained in two $7,570-\mathrm{L}$ (2,000-gal) tanks; however, the total volume of acid never exceeds 11,360 L (3,000 gal). An additional $415 \mathrm{~L}$ (110 gal) of concentrated sulfuric acid [approximately 93 percent $(35 \mathrm{~N})$ solution] may be found in two 208-L (55-gal) day tanks, also in Building E near the resource recovery area. This 415-L (110-gal) amount represents a recent reduction in $\mathrm{H}_{2} \mathrm{SO}_{4}$ used in the day tanks based on a commitment by NMI to decrease the amount in one of the tanks from $570 \mathrm{~L}$ (150 gal) to $208 \mathrm{~L}$ (55 gal) (D.S. Schlier and G. Shinopulos, Nuclear Metals, Inc., Concord, Mass., office memorandum, "Sulfuric Acid Use in E Building," to E. Anderson, Nuclear Metals, Inc., Concord, Mass., July 30, 1996). One drum [340 kg (750 lb) net weight; approximately $190 \mathrm{~L}$ (50 gal)] of concentrated sulfuric acid may also be present in Building $\mathrm{E}$ near the resource recovery area. Based on these volumes and concentrations, the total quantity of $\mathrm{H}_{2} \mathrm{SO}_{4}$ in Building $\mathrm{E}$ is $2,030 \mathrm{~kg}(4,480 \mathrm{lb})$, as shown in Table 3.10 . Up to four drums of concentrated sulfuric acid containing a total of $760 \mathrm{~L}$ ( $200 \mathrm{gal}$ ) may also be present in the receiving area. As shown in Table 3.10, the total quantity of $\mathrm{H}_{2} \mathrm{SO}_{4}$ in the receiving area is $1,270 \mathrm{~kg}(2,800 \mathrm{lb})$.

The $\mathrm{HBF}_{4}$ is present in a 2 percent $(0.16 N)$ solution, but only in a single $19-\mathrm{L}$ (5-gal) tank. In large enough quantities, each of these acids is hazardous to humans. However, the quantity of $\mathrm{HBF}_{4}$ stored at the facility is so small that an atmospheric release of the entire amount would have a negligible impact on the environment. Therefore, $\mathrm{HBF}_{4}$ is not analyzed further. 
Table 3.10. Volumes of acids present at Nuclear Metals, Inc. facilities and corresponding quantities of the hazardous substances contained within the acid solutions

\begin{tabular}{lllcc}
\hline \multicolumn{1}{c}{ Acid } & $\begin{array}{c}\text { Acid concentration } \\
\text { [percent (normality)] }\end{array}$ & $\begin{array}{c}\text { Acid volume } \\
{[\mathrm{L}(\mathrm{gal})]}\end{array}$ & $\begin{array}{c}\text { Hazardous } \\
\text { substance }\end{array}$ & $\begin{array}{c}\text { Quantity of } \\
\text { hazardous } \\
\text { substance } \\
\left(\mathrm{kg}^{a}\right)\end{array}$ \\
\hline Hydrochloric & $20(2.4 \mathrm{~N})$ & $415(110)$ & $\mathrm{HCl}$ & 36 \\
Hydrofluoric & $50(10.9 \mathrm{~N})$ & $415(110)$ & $\mathrm{HF}$ & 91 \\
Sulfuric & $5(1.8 \mathrm{~N})$ & $11,360(3,000)$ & $\mathrm{H}_{2} \mathrm{SO}_{4}$ & $1,000^{b}$ \\
Sulfuric & $93(35 \mathrm{~N})$ & $605(160)$ & $\mathrm{H}_{2} \mathrm{SO}_{4}$ & $1,030^{b}$ \\
Sulfuric & $93(35 \mathrm{~N})$ & $760(200)$ & $\mathrm{H}_{2} \mathrm{SO}_{4}$ & $1,270^{c}$ \\
Fluoroboric & $2(0.16 \mathrm{~N})$ & $19(5)$ & $\mathrm{HBF}_{4}$ & 0.3 \\
\hline
\end{tabular}

${ }^{a} 1 \mathrm{~kg}=2.2 \mathrm{lb}$.

${ }^{b}$ This material is located in Building $\mathrm{E}$, near the resource recovery area. The combined $\mathrm{H}_{2} \mathrm{SO}_{4}$ quantity in Building $\mathrm{E}$ is $2,030 \mathrm{~kg}$ (the sum of $1,000 \mathrm{~kg}$ and $1,030 \mathrm{~kg}$ ); of this amount, only $1,620 \mathrm{~kg}$ is deemed credible as an upper bound on the available source term for use in accident analyses (see text for additional details).

${ }^{c}$ This material is located in the receiving area of the B-4 building.

The evaluation of the potential impacts of these nonradiological materials was based on a release to the atmosphere using the same accidental fire scenario as for the radiological materials. The analysis of the atmospheric dispersion of these nonradiological materials followed the same set of assumptions and procedures discussed in Section 3.1.2.3, with the exception that the primary release mechanism was assumed to be the evaporation or volatilization of the hazardous acids due to the heat of the fire. Once airborne, the hazardous materials were assumed to be entrained by the thermal effects of the fire and dispersed in the atmosphere as they traveled downwind. The potentially affected individual was assumed to be

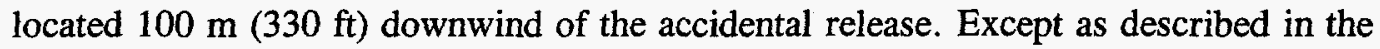
paragraphs below for $\mathrm{H}_{2} \mathrm{SO}_{4}$, the source term for each of the acid hazards was taken to be the maximum amount of hazardous substance presented in Table 3.10. 
Because a nearly total failure of fire safety systems during a hot, lengthy fire would be required to vaporize the large quantity of sulfuric acid present, the entire amount of $\mathrm{H}_{2} \mathrm{SO}_{4}$ at NMI was deemed to be inappropriate for use as a source term in the accident analysis. An upper bound on the material potentially at risk was derived from three considerations: (1) a credible fire would affect the acid inventory in a single building only (corresponding to the analysis for a fire involving radiological materials); (2) floor drains are present in the immediate vicinity of the sulfuric acid tanks and drums in Building E; and (3) approximately $30,300 \mathrm{~L}(8,000 \mathrm{gal})$ of liquid are contained in wastewater treatment tanks adjacent to the resource recovery area in Building $\mathrm{E}$.

In the event of a fire in Building $\mathrm{E}$, the plastic wastewater tanks would fail, dumping their contents on the floor and diluting any acid present. In addition, the majority of water piping in Building $E$ is plastic and would fail in a fire, allowing additional dilution of any spilled sulfuric acid. Further, the sprinkler system would flood the area with water at a rate of $13 \mathrm{~L} / \mathrm{s}(200 \mathrm{gpm})$. For the purposes of this analysis, however, it is assumed that the entire amount of sulfuric acid in Building $E$ is spilled in an accident and that only the liquid in the wastewater tanks is available to dilute the spilled acid. The total amount of liquid (acid plus wastewater) on the floor in Building E would thus be 42,265 L (11,160 gal).

Five floor drains near the sulfuric acid in Building $\mathrm{E}$ have the capacity to remove about $28 \mathrm{~L} / \mathrm{s}(450 \mathrm{gpm})$ of liquid; thus, if the total 11,965 L (3,160 gal) of sulfuric acid were the only liquid on the floor, it could be removed from the building in just over 7 minutes, an inadequate time for significant vaporization to occur during a fire. On the other hand, if the total volume of wastewater plus acid were spilled, the drains would remove all of the liquids from the building in about 28 minutes. For the purposes of this analysis, it is conservatively assumed that the drains would only operate for 5 minutes before becoming plugged by debris from the fire.

With 5 minutes of drain operation and with $42,265 \mathrm{~L}(11,160 \mathrm{gal})$ of wastewater plus sulfuric acid spilled on the floor, a total of $1,620 \mathrm{~kg}(3,570 \mathrm{lb})$ of $\mathrm{H}_{2} \mathrm{SO}_{4}$ (about $80 \%$ of the total $\mathrm{H}_{2} \mathrm{SO}_{4}$ initially in the tanks, drums, and day tanks in Building E) would remain inside the building and would be available for vaporization and subsequent atmospheric dispersion in the event of a fire. Because this quantity is greater than the $1,270 \mathrm{~kg}(2,800 \mathrm{lb})$ stored in the four 
drums in the receiving area of the B-4 building (see Table 3.10), and because only one building is assumed to be affected by a credible fire, the $1,620 \mathrm{~kg}(3,570 \mathrm{lb})$ from Building $\mathrm{E}$ was used as the $\mathrm{H}_{2} \mathrm{SO}_{4}$ source term in the dispersion analyses below.

Table 3.11 displays the maximum predicted concentrations and related exposure limits of concern for each of the acid hazards. In addition to the ERPG-2 limit defined earlier, the exposure limits are: (1) the ERPG-3 limit, established by the American Industrial Hygiene Association as the maximum concentration to which it is believed that nearly all individuals could be exposed for up to $1 \mathrm{hr}$ without experiencing or developing life-threatening health effects; (2) the immediately dangerous to life and health (IDLH) threshold value, established by the National Institute of Occupational Safety and Health (NIOSH) as the maximum atmospheric concentration from which a person could escape within 30 minutes without a respirator and without experiencing irreversible health effects or escape-impairing effects (e.g., severe eye irritation); and (3) the $\mathrm{LC}_{50}$, the concentration which would result in fatalities to 50 percent of the exposed population. The limits are expressed as concentrations in breathable air and are stated in conjunction with an applicable duration of exposure.

Each acid hazard was analyzed separately, and no combinations or synergistic effects were included in the analysis. In relation to the analysis presented in Section 3.1.2.4, the following assumptions were made for these hazardous materials:

- Except for $\mathrm{H}_{2} \mathrm{SO}_{4}$, the damage ratio was assumed to be 100 percent $(D R=1.0)$; that is, the entire acid inventory was assumed to be affected by the fire. For $\mathrm{H}_{2} \mathrm{SO}_{4}$, the damage ratio was assumed to be 80 percent, as discussed above.

- The release fraction was assumed to be 100 percent $(R F=1.0)$; that is, the entire affected inventory was assumed to become airborne.

- The respirable fraction was assumed to be 100 percent $\left(r_{f}=1.0\right)$; that is, the entire airborne quantity was assumed to be respirable. This is consistent with the vaporous nature of these acids.

Although the collective set of above values is conservative and will overestimate the amount of nonradioactive hazardous material reaching a downwind individual, the above values are used in the accident analysis due to the lack of better data. 
Table 3.11 Maximum predicted concentrations and related exposure limits associated with acid hazards at Nuclear Metals, Inc. facilities

\begin{tabular}{|c|c|c|c|c|c|}
\hline $\begin{array}{c}\text { Hazardous } \\
\text { substance }\end{array}$ & $\begin{array}{l}\text { Maximum } \\
\text { concentration } \\
\left(\mathrm{mg} / \mathrm{m}^{3}\right)^{a}\end{array}$ & $\begin{array}{l}\text { Type of } \\
\text { exposure } \\
\text { limit }^{b}\end{array}$ & $\begin{array}{c}\text { Value of } \\
\text { exposure limit } \\
\left(\mathrm{mg} / \mathrm{m}^{3}\right)\end{array}$ & $\begin{array}{c}\text { Associated } \\
\text { exposure period } \\
\text { (minutes) }\end{array}$ & $\begin{array}{l}\text { Ratio of concentration } \\
\text { to exposure limit } \\
\text { (in percent) }\end{array}$ \\
\hline \multirow[t]{4}{*}{$\mathrm{HCl}$} & 17 & IDLH & 75 & 30 & 23 \\
\hline & & ERPG-2 & 30 & 60 & 57 \\
\hline & & ERPG-3 & 149 & 60 & 11 \\
\hline & & $\mathrm{LC}_{50}$ & 1,400 & 120 & 1 \\
\hline \multirow[t]{4}{*}{$\mathrm{HF}$} & 42 & IDLH & 25 & 30 & 168 \\
\hline & & ERPG-2 & 16 & 60 & 263 \\
\hline & & ERPG-3 & 58 & 60 & 72 \\
\hline & & $\mathrm{LC}_{50}$ & 650 & 120 & 6 \\
\hline \multirow[t]{4}{*}{$\mathrm{H}_{2} \mathrm{SO}_{4}$} & $740^{c}$ & IDLH & 15 & 30 & 4,933 \\
\hline & & ERPG-2 & 10 & 60 & 7,400 \\
\hline & & ERPG-3 & 30 & 60 & 2,467 \\
\hline & & $\mathrm{LC}_{50}$ & 850 & 120 & 87 \\
\hline
\end{tabular}

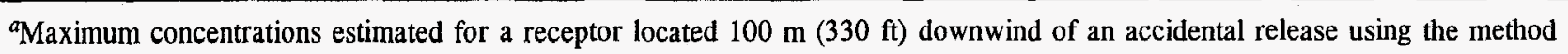
outlined in Sect. 3.1.2.4.

${ }^{b} \mathrm{IDLH}=$ immediately dangerous to life and health; ERPG-2 = Emergency Response Planning Guideline-Level 2;

ERPG-3 = Emergency Response Planning Guideline-Level 3; $\mathrm{LC}_{50}=$ concentration which would result in fatalities to 50 percent of the exposed population.

'Maximum concentration calculated assuming 1,620 kg of $\mathrm{H}_{2} \mathrm{SO}_{4}$ in Building $\mathrm{E}$ is released in a 2-hr period. 
HCl. The predicted 2-hr concentration that results from the entire mass of $\mathrm{HCl}$ being released to the atmosphere in a fire is $17 \mathrm{mg} / \mathrm{m}^{3}$. The ERPG- 2 for $\mathrm{HCl}$ is $30 \mathrm{mg} / \mathrm{m}^{3}$, the ERPG-3 is $149 \mathrm{mg} / \mathrm{m}^{3}$, and the IDLH is $75 \mathrm{mg} / \mathrm{m}^{3}$. The predicted concentration is below the level that would cause irreversible effects, but it is above the irritation threshold of $15 \mathrm{mg} / \mathrm{m}^{3}$.

Therefore, an exposed person would not be expected to voluntarily stay in the plume but would leave the plume, if capable. In addition, the predicted 2-hr concentration is well below the $\mathrm{LC}_{50}$ of $1,400 \mathrm{mg} / \mathrm{m}^{3}$ for a 2 -hr exposure to $\mathrm{HCl}$.

HF. The predicted 2-hr concentration that results from the entire mass of HF being released to the atmosphere is $42 \mathrm{mg} / \mathrm{m}^{3}$. The ERPG-2 for HF is $16 \mathrm{mg} / \mathrm{m}^{3}$ and the IDLH is $25 \mathrm{mg} / \mathrm{m}^{3}$. The predicted concentration is above the ERPG- 2 and IDLH, but it is below the ERPG- 3 of $58 \mathrm{mg} / \mathrm{m}^{3}$. The predicted concentration is well below the $\mathrm{LC}_{50}$ of $650 \mathrm{mg} / \mathrm{m}^{3}$ for a $2-\mathrm{hr}$ exposure to HF. With an irritation threshold of $15 \mathrm{mg} / \mathrm{m}^{3}$, HF is irritating at the predicted concentration and would not be tolerated voluntarily by a person exposed to the plume.

$\mathrm{H}_{2} \mathrm{SO}_{4}$. Assuming that $1,620 \mathrm{~kg}$ of $\mathrm{H}_{2} \mathrm{SO}_{4}$ is released from Building $\mathrm{E}$ to the atmosphere in a fire, the maximum estimated $2-\mathrm{hr}$ concentration is $740 \mathrm{mg} / \mathrm{m}^{3}$. Because this concentration is greater than that predicted for the $1,270 \mathrm{~kg}$ of $\mathrm{H}_{2} \mathrm{SO}_{4}$ in the receiving area, the latter is not presented. The ERPG-2 for $\mathrm{H}_{2} \mathrm{SO}_{4}$ is $10 \mathrm{mg} / \mathrm{m}^{3}$, the ERPG-3 is $30 \mathrm{mg} / \mathrm{m}^{3}$, the IDLH is $15 \mathrm{mg} / \mathrm{m}^{3}$, and the $\mathrm{LC}_{50}$ for a 2 -hr exposure is $850 \mathrm{mg} / \mathrm{m}^{3}$. The predicted concentration of $\mathrm{H}_{2} \mathrm{SO}_{4}$ is below the $\mathrm{LC}_{50}$ but higher than the ERPG levels. The potential impact of $\mathrm{H}_{2} \mathrm{SO}_{4}$ is a concern; however, with an irritation threshold of $2 \mathrm{mg} / \mathrm{m}^{3}, \mathrm{H}_{2} \mathrm{SO}_{4}$ would not be tolerated voluntarily at the predicted level for more than a few seconds. NMI is prepared to discuss the potential for an accidental $\mathrm{H}_{2} \mathrm{SO}_{4}$ release with local emergency response officials (see Section 3.1.5).

All of the acids are very irritating to the mucous membranes and eyes. For all of the acids, the irritating symptoms occur at relatively low concentrations with respect to concentrations likely to result in serious health effects. Thus, a person with any mobility would not remain in the plume for more than minutes, and possibly seconds. The nature of a 
fire is that a period of time would be required for high temperatures to develop, after which time the acids would heat up and begin to boil/evaporate. Thus, there would be an increasing concentration during the beginning phase of the acid release. None of the concentrations would be high enough to cause mortality from an exposure of a few seconds, but they would be high enough to cause appreciable irritation within seconds to minutes.

\subsubsection{Environmental Justice}

On April 21, 1995, NRC's NMSS issued Policy and Procedures Letter 1-50, Revision 1, titled "Environmental Justice in NEPA Documents," providing interim guidance for compliance with Executive Order 12898 on Environmental Justice to serve until guidelines are available from the Council on Environmental Quality (CEQ). The purpose of Executive Order 12898 is to ensure that minority and low-income populations do not suffer "disproportionately high adverse human health or environmental effects" as a result of federal programs, policies, and activities. NRC interim guidance further stipulates that the potential for environmental justice concerns can exist only if minorities or households in poverty exceed state or county averages by 20 percent.

Because of the rural nature of the area, this assessment to evaluate environmental justice considers a potential area of impact recommended by NMSS for rural regions [i.e., a $130 \mathrm{~km}^{2}$ $\left(50 \mathrm{mile}^{2}\right)$ area around the site which has a radius equal to $6.5 \mathrm{~km}$ (4 miles)]. This area includes parts of the incorporated towns of Concord, Acton, Sudbury, and Maynard. Following consultation with planners in each of the four towns (Alfred Lima, Director of Concord Office of Planning and Land Management; Acton Planning Department; Dorothy Burke, Sudbury Planning Office; and Judy Peterson, Maynard Planning Office, personal communication with Inga E. Treitler, Oak Ridge National Laboratory, Oak Ridge, Tenn., April 26, 1995), a site visit and assessment by ORNL staff (May 11, 1995), and a literature search (e.g., Garrelick 1992:147-174), the staff determined that the population in the four towns is reasonably homogeneous and that population data gathered for each of these towns could be considered representative of the area within the $6.5-\mathrm{km}$ (4-mile) radius. The following data were collected for these four towns: 
1. 1990 census data on racial composition, including percent of total population that is black; Asian or Pacific Islander; American Indian, Eskimo, or Aleut; and other race (Table 3.12). The percent Hispanic is also displayed in Table 3.12. Comparable data for Middlesex County and the state of Massachusetts are included for comparison.

2. 1990 income data, including percent below poverty level and total income ranges, to provide an overview of the socioeconomic structure in the towns surrounding the site (Table 3.13).

Income distribution data available for this analysis are for households of 2.55 persons, which is the average national household size; the average household size in Middlesex County is 2.26 persons. Poverty level is not defined in the census for average household, but for households of varying sizes, including 3 persons. A poverty level for a household of 3 , which is an income of $\$ 9,885$, was used to estimate the number of households below poverty level.

Minorities. Minority and Hispanic populations comprise 6.7 percent and 3.4 percent of the population in Middlesex County, respectively, and 7.6 percent and 4.8 percent of the population in the state of Massachusetts, respectively. In all four towns of the impact region, the percent minority and percent Hispanic are below those of both the county and state. Therefore, there is no potential for environmental justice concerns based on race or ethnicity.

Low income. Based on consultation and independent assessment to supplement the census data, it was found that people with lower income levels in these four towns tend to be those who have inherited family homes or elderly populations who are on fixed incomes. Their expenses tend to be lower than those of a young family with typical expenses such as home mortgages and automobile payments. Many have historical roots in the area, raised their families, and continue to inhabit family-owned homes (Alfred Lima, Director of Concord Office of Planning and Land Management, personal communication with Inga Treitler, Oak Ridge National Laboratory, Oak Ridge, Tenn., May 4, 1995).

In all four towns the percentage of households below poverty level is less than the rate of poverty in the state (13.4 percent). Although the percentage of households in poverty in Maynard (8.9 percent) exceeds the percentage in Middlesex County (8.2 percent), the 
Table 3.12. Racial and ethnic composition of towns within a four-mile radius of Nuclear Metals, Inc. (percent of total in parentheses)

\begin{tabular}{|c|c|c|c|c|c|c|c|c|}
\hline \multirow[b]{2}{*}{ Location } & \multicolumn{4}{|c|}{ Minority races } & \multirow[b]{2}{*}{ White } & \multirow[b]{2}{*}{ Other race } & \multirow[b]{2}{*}{ Total $^{b}$} & \multirow[b]{2}{*}{ Hispanic $^{c}$} \\
\hline & Black $^{\mathrm{a}}$ & $\begin{array}{l}\text { American } \\
\text { Indian, } \\
\text { Eskimo, or } \\
\text { Aleut }^{a}\end{array}$ & $\begin{array}{l}\text { Asian, or } \\
\text { Pacific } \\
\text { Islander }\end{array}$ & $\begin{array}{l}\text { Total } \\
\text { minority } \\
\text { races }\end{array}$ & & & & \\
\hline Acton & $\begin{array}{l}160 \\
(0.9)\end{array}$ & $\begin{array}{l}20 \\
(0.1)\end{array}$ & $\begin{array}{l}647 \\
(3.6)\end{array}$ & $\begin{array}{l}827 \\
(4.6)\end{array}$ & $\begin{array}{l}16,992 \\
(95.1)\end{array}$ & $\begin{array}{l}53 \\
(0.3)\end{array}$ & 17,872 & $\begin{array}{l}206 \\
(1.2)\end{array}$ \\
\hline Concord & $\begin{array}{l}454 \\
(2.7)\end{array}$ & $\begin{array}{l}27 \\
(0.2)\end{array}$ & $\begin{array}{l}349 \\
(2.0)\end{array}$ & $\begin{array}{l}830 \\
(4.9)\end{array}$ & $\begin{array}{l}15,988 \\
(93.6)\end{array}$ & $\begin{array}{l}258 \\
(1.5)\end{array}$ & 17,076 & $\begin{array}{l}514 \\
(3.0)\end{array}$ \\
\hline Maynard & $\begin{array}{l}86 \\
(0.8)\end{array}$ & $\begin{array}{l}15 \\
(0.1)\end{array}$ & $\begin{array}{l}186 \\
(1.8)\end{array}$ & $\begin{array}{l}287 \\
(2.8)\end{array}$ & $\begin{array}{l}9,952 \\
(96.4)\end{array}$ & $\begin{array}{l}86 \\
(0.8)\end{array}$ & 10,325 & $\begin{array}{l}240 \\
(2.3)\end{array}$ \\
\hline Sudbury & $\begin{array}{l}184 \\
(1.3)\end{array}$ & $\begin{array}{l}16 \\
(0.1)\end{array}$ & $\begin{array}{l}417 \\
(2.9)\end{array}$ & $\begin{array}{l}617 \\
(4.3)\end{array}$ & $\begin{array}{l}13,714 \\
(95.5)\end{array}$ & $\begin{array}{l}27 \\
(0.2)\end{array}$ & 14,358 & $\begin{array}{l}136 \\
(0.9)\end{array}$ \\
\hline $\begin{array}{l}\text { Middlesex } \\
\text { County }\end{array}$ & $\begin{array}{l}40,236 \\
(2.9)\end{array}$ & $\begin{array}{l}1,933 \\
(0.1)\end{array}$ & $\begin{array}{l}51,826 \\
(3.7)\end{array}$ & $\begin{array}{l}93,995 \\
(6.7)\end{array}$ & $\begin{array}{l}1,2287,412 \\
(92.1)\end{array}$ & $\begin{array}{l}17,061 \\
(1.2)\end{array}$ & $1,398,468$ & $\begin{array}{l}47,383 \\
(3.4)\end{array}$ \\
\hline $\begin{array}{l}\text { State of } \\
\text { Massachusetts }\end{array}$ & $\begin{array}{l}300,130 \\
(5.0)\end{array}$ & $\begin{array}{l}12,241 \\
(0.2)\end{array}$ & $\begin{array}{l}143,392 \\
(2.4)\end{array}$ & $\begin{array}{l}55,763 \\
(7.6)\end{array}$ & $\begin{array}{l}5,405,374 \\
(89.3)\end{array}$ & $\begin{array}{l}155,288 \\
(2.6)\end{array}$ & $6,016,425$ & $\begin{array}{l}287,549 \\
(4.8)\end{array}$ \\
\hline
\end{tabular}

${ }^{a}$ These racial groups are categorized as minorities by the Nuclear Material Safety and Safeguards interim guidance for compliance with Executive Order 12898

${ }^{b}$ Total population is the sum of the columns for total minority, white, and other race.

cPersons of Hispanic origin may be of any race. Therefore, the percent of total is based on the "Total" column.

Source: Census of Population and Housing, 1990, Summary Tape File 1A on CD-ROM. 
Table 3.13. Income distribution in dollars per household for towns within a four-mile radius of Nuclear Metals, Inc. (percent of total in parentheses) ${ }^{a}$

\begin{tabular}{lllllll}
\hline Income Ranges $(\$)$ & \multicolumn{1}{c}{ Acton } & \multicolumn{1}{c}{ Concord } & Maynard & Sudbury & $\begin{array}{c}\text { Middlesex } \\
\text { County }\end{array}$ & $\begin{array}{c}\text { State of } \\
\text { Massachusetts }\end{array}$ \\
\hline Up to 5,000 & $72(1.1)$ & $37(0.7)$ & $114(2.8)$ & $90(1.9)$ & $16,509(2.7)$ & $91,295(4.1)$ \\
5,000 to 9,999 & $213(3.2)$ & $220(3.9)$ & $248(6.1)$ & $66(1.4)$ & $34,140(5.5)$ & $209,406(9.3)$ \\
Total below & $285(4.3)$ & $257(4.6)$ & $362(8.9)$ & $156(3.3)$ & $50,649(8.2)$ & $300,701(13.4)$ \\
poverty level & & & & & & \\
10,000 to 24,999 & $661(10.1)$ & $581(10.3)$ & $761(18.7)$ & $340(7.2)$ & $84,680(13.7)$ & $446,162(19.9)$ \\
25,000 to 34,999 & $703(10.7)$ & $370(6.6)$ & $470(11.5)$ & $295(6.3)$ & $65,482(10.6)$ & $309,733(13.8)$ \\
35,000 to 49,999 & $995(15.1)$ & $585(10.4)$ & $720(17.7)$ & $364(7.7)$ & $94,319(15.2)$ & $417,050(18.6)$ \\
50,000 to 74,999 & $1,405(21.4)$ & $1,192(21.1)$ & $993(24.4)$ & $997(21.1)$ & $115,363(18.6)$ & $441,645(19.7)$ \\
75,000 to 99,999 & $1,152(17.5)$ & $912(16.2)$ & $467(11.5)$ & $931(19.7)$ & $55,828(9.0)$ & $178,806(8.0)$ \\
100,000 and up & $1,373(20.9)$ & $1,744(30.9)$ & $297(7.3)$ & $1,631(34.6)$ & $152,700(24.7)$ & $149,309(6.7)$ \\
Total & 6,574 & 5,641 & 4,070 & 4,714 & 619,021 & $2,243,406$ \\
\hline
\end{tabular}

${ }^{a} \mathrm{~A}$ household is defined as 2.55 persons. In this table, the poverty level of a household of 3 persons, which in 1989 was an income of $\$ 9,885$, is used to estimate the number of households in poverty.

Source: Town Clerk's Office, Community Profile, prepared by the Executive Office of Communities and Development, Commonwealth of

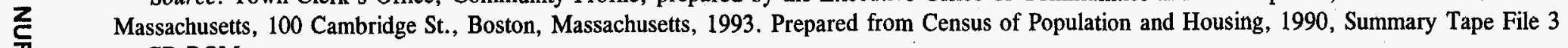
on CD-ROM. 
0.7 percent difference is well below the threshold of 20 percent specified in the interim NRC guidance. Because of its history as a mill town, Maynard is characterized by a working class population and has less expensive housing than surrounding towns (Carrie Flood, Concord town council member, Concord, Massachusetts, personal communication with Inga Treitler, Oak Ridge National Laboratory, Oak Ridge, Tenn., May 11, 1995). Therefore, there is no potential for environmental justice concerns based on income.

\subsubsection{Cumulative Impacts}

This section evaluates potential environmental impacts from existing or proposed facilities or activities in the region which, combined with the proposed license renewal, may contribute to cumulative impacts. At NMI, there are atmospheric emissions of nonradiological pollutants, such as beryllium, that are not subject to NRC licensing. Beryllium emissions, similar to radionuclide emissions, are classified as human carcinogens and are regulated under NESHAPs. During 1994, NMI emitted a total of $0.7 \mathrm{~g}(0.002 \mathrm{lb})$ of beryllium to the atmosphere. This total annual amount is only 7 percent of the $10 \mathrm{~g}(0.022 \mathrm{lb})$ daily emission limit specified in NESHAPs (40 CFR 61.32). In 1994, the highest daily average emission rate was $0.011 \mathrm{~g}\left(2.4 \times 10^{-5} \mathrm{lb}\right)$, which is 0.11 percent of the daily NESHAP standard. Using conservative assumptions (i.e., assumptions that form an upper bound of cancer risk), the cancer risk from a person inhaling beryllium emitted from NMI over a lifetime is much less than one-in-one million. Therefore, there would be negligible cumulative impacts associated with beryllium emissions and radionuclide emissions.

Impacts from regional sources of criteria pollutants were incorporated into the air quality analyses in Section 3.1.1.3 because background concentrations from nearby monitors were added to maximum modeled concentrations to determine total impacts. The effect of other emissions was accounted for in these background concentrations; thus, cumulative impacts to ambient air quality would be the same as those described in Section 3.1.1.3. There are no major hazardous pollutant sources (radiological or nonradiological) in the vicinity of NMI that would contribute a cumulative impact to atmospheric resources. 
As discussed in Section 1.2, groundwater at the NMI site has been contaminated by past uranium and nitrate discharges from NMI, and the potential exists for offsite migration of the uranium plume. Because nitrate migrates more quickly and is diluted more than uranium, its concentrations about $18 \mathrm{~m}$ (60 ft) deep in the overburden have decreased substantially both on and off the site. Except for drinking water which is obtained from the city of Concord, all of the supply water is provided by two onsite supply wells, designated as SW-1 and SW-2a (see Figure 1.2). SW-1, which is located on the northern side of the NMI property, extends about $18 \mathrm{~m}(60 \mathrm{ft})$ deep into overburden and can supply about 1,140 to $1,510 \mathrm{~L}$ per minute (300 to $400 \mathrm{gpm}$ ) of water. No uranium contamination has been detected at SW-1. SW-2a, which is located on the southern side of the NMI property immediately to the west of the holding basin, extends about $150 \mathrm{~m}(500 \mathrm{ft})$ into bedrock and can supply about $570 \mathrm{~L}$ per minute $(150 \mathrm{gpm})$ of water. Slight uranium contamination $(0.013 \mathrm{mg} / \mathrm{L})$ has been detected at $\mathrm{SW}-2 \mathrm{a}$.

Non-contact process water used by NMI for cooling is discharged into an onsite cooling water pond. The water then seeps back into the groundwater, and about two-thirds of the supply water at SW-1 arrives by migration from the cooling water pond; thus, the flow of water forms a loop. The migration of water from the cooling water pond has altered the movement of the uranium plume. In the absence of seepage from the pond, the plume would have moved to the north toward the Assabet River. Because of the pond seepage, the plume initially moves to the northwest before changing to a northerly direction while still within the NMI site. In addition, the seepage may dilute the uranium concentrations. While the seepage may also dilute the nitrate concentrations, a small portion of the nitrate is recycled in the loop formed by the withdrawal of supply water at SW-1 and the migration of water from the cooling water pond back to SW-1. Except for the above mentioned effects, potential environmental impacts from current NMI operations are independent of those associated with groundwater contamination from past operations because discharges from uranium processing are now recycled and small amounts of water in liquid wastes are evaporated. NRC plans to undertake a separate action to evaluate activities to remediate the holding basin and contaminated groundwater. 


\subsubsection{Mitigation Measures}

Mitigation measures have been developed to minimize potential environmental impacts associated with operation of the NMI facility. NMI reports the quantities and locations of hazardous materials on an annual basis, as required under regulations promulgated for the Community Right-to-Know Act. NMI also works with the local fire department and HAZMAT (hazardous materials) District No. 14 to familiarize emergency response personnel with NMI's layout and inventory of radiological and chemical hazards. NMI provides tours for these personnel at least once per year.

With regard to an accidental release of $\mathrm{H}_{2} \mathrm{SO}_{4}$, the maximum predicted concentration in the ambient air exceeds the ERPG levels. However, because the irritation threshold for $\mathrm{H}_{2} \mathrm{SO}_{4}$ is sufficiently less than the ERPG levels, all able-bodied people would be capable of speedily and voluntarily evacuating. These findings were forwarded to the Massachusetts Department of Environmental Protection and the Massachusetts Department of Public Health-Radiation Control Program. Further, NMI has committed to NRC to provide a briefing for the local emergency response officials to discuss the potential for an accidental $\mathrm{H}_{2} \mathrm{SO}_{4}$ release resulting in downwind concentrations greater than the ERPG levels.

With regard to $\mathrm{SO}_{2}$ emissions during normal operations, $\mathrm{NMI}$ is prepared to undertake mitigative action to prevent potential exceedances of the short-term $\mathrm{SO}_{2} \mathrm{NAAQS}$. Although NMI has not yet committed to a specific mitigation measure, the Massachusetts Department of Environmental Protection and NMI have initiated a dialogue to remediate the predicted exceedances in an expeditious manner. The issue will be resolved via a permit/approval change or through a Consent Order issued by the Massachusetts Department of Environmental Protection (MacDonald 1996).

\subsection{ENVIRONMENTAL CONSEQUENCES OF NO ACTION}

Under the no-action alternative, NRC would not renew NMI's licenses and all processing, handling, storage, and other operations involving radioactive material would cease 
at the facility. However, operations, involving nonradioactive material (e.g., beryllium processing) would continue. Therefore, criteria pollutant emissions associated with the boiler would be expected to continue at levels equal to or below current operations, and impacts would be the same as or slightly less than those described in Section 3.1.1.3. Because radionuclide emissions would cease with the no-action alternative, there would be no radiological impact.

Socioeconomic resources would be affected by the no-action alternative. As a result of the production of depleted uranium penetrators, NMI staff increased from 125 in the mid-1970s to 750 by 1983 . Since then, competition from within the industry and decreased military needs reduced staff back to 130 by May 1995. Efforts are being made to find other uses for existing staff and decommissioned production space (Bob Quinn, president of Nuclear Metals, Inc., Concord, Massachusetts, personal communication with Inga E. Treitler, Oak Ridge National Laboratory, Oak Ridge, Tenn., May 11, 1995). The current number of workers is 143 .

In Fiscal Year 1995, 38 percent of NMI's production was related to activities requiring an NRC license and 62 percent was related to nonradioactive material; about 50 percent of the workforce at NMI are involved in NRC-regulated activities. The no-action alternative could thus impact the jobs of approximately 72 employees at NMI, about half of whom would be retrained. Economic impacts would be incurred by the company in the retraining. About 36 employees would be dismissed, resulting in a small economic effect on the region. Because fewer than 10 employees live in the four towns that surround NMI (Frank Vumbaco, Nuclear Metals, Inc., personal communication with Inga Treitler, Oak Ridge National Laboratory, Oak Ridge, Tenn., September 26,1995 ), layoffs would have only minimal economic impacts on the immediate area around the facility. 


\section{REFERENCES}

Andersen, E. B. 1996. Letter to R. Miller, Oak Ridge National Laboratory, dated January 26.

Byrne, M. R. and R. Codell 1994. Analysis of Nuclear Metals Site, attachment to a memorandum from Margaret Federline, Performance Assessment and Hydrology Branch, to John Austin, Low-Level Waste and Decommissioning Projects Branch, Division of Waste Manàgement, Office of Nuclear Materials Safety and Safeguards, Nuclear Regulatory Commission, October 3.

Carter, R. F., and K. Stewart 1970. "On the Oxide Fume Formed by the Combustion of Plutonium and Uranium," in Inhaled Particles III, W. H. Walton, Ed., Unwin Brothers Limited, The Gresham Press, Old Working, Surrey, England.

CREW (Citizen's Research and Environmental Watch) 1994. Soil Samples and Tests Off-Site from Nuclear Metals, Inc., available from Gary Newman, (508) 369-4207, or Sumin Tchen, (617) 497-5159, Concord, Massachusetts.

DEP (Massachusetts Department of Environmental Protection) 1995. Final Restricted Emission Status Approval for Nuclear Metals, Inc., Concord, Massachusetts, Transmittal No. 93985, App. No. MBR-94-RES-071, Woburn, Massachusetts.

Elder, J. C., and M. C. Tinkle 1980. Oxidation of Depleted Uranium Penetrators and Aerosol Dispersal at High Temperatures, LA-8610-MS, Los Alamos Scientific Laboratory, Los Alamos, New Mexico.

EPA (U. S. Environmental Protection Agency) 1980. Manual of Protective Action Guides and Protective Actions for Nuclear Incidents, EPA-520/1-75-001, U.S. Environmental Protection Agency, Washington, D.C.

EPA (U. S. Environmental Protection Agency) 1992a. User's Guide for the Industrial Source Complex (ISC2) Dispersion Models, Volume I: User Instructions, EPA Publication No. EPA-450/4-92-008a, Office of Air Quality and Planning Standards, Research Triangle Park, North Carolina.

EPA (U. S. Environmental Protection Agency) 1992b. SCREEN2 User's Guide, EPA-450/4-92-006, Office of Air Quality and Planning Standards, Research Triangle Park, North Carolina. 
EPA (U. S. Environmental Protection Agency) 1995. Supplement $C$ to the Guideline on Air Quality Models (Revised) (Appendix W of 40 CFR Part 51), EPA-450/2-78-027R-C (NTIS No. PB 95-246401), Office of Air Quality and Planning Standards, Research Triangle Park, North Carolina.

EPA (U. S. Environmental Protection Agency) 1989. A Guide for Determining Compliance with the Clean Air Act Standards for Radionuclide Emissions from NRC-Licensed and Non-DOE Facilities (Revision 2), EPA 520/1-89-002, Office of Radiation and Indoor Air, Washington, D. C.

EPA (U. S. Environmental Protection Agency) 1987. On-Site Meteorological Program Guidance for Regulatory Modeling Applications, EPA-450/4-87-013, Office of Air Quality and Planning Standards, Research Triangle Park, North Carolina.

Garrelick, R. 1992. Concord in the Days of Strawberries and Streetcars, second edition.

GZA (Geoenvironmental, Inc.) 1994b. Results of Field Investigation Phase II-Comprehensive Site Assessment, Nuclear Metals, Inc., Concord, Massachusetts, File No. 7875.2, Newton Upper Falls, Massachusetts.

GZA (Geoenvironmental, Inc.) 1994a. Environmental Summary Report, Nuclear Metals, Inc., File No. 7875.4, Prepared for Nuclear Metals, Inc., Newton Upper Falls, Massachusetts.

Haley and Aldrich, Inc. 1990. Report on Evaluation of Uranium in Soil and Groundwater, M.D.T. Concord Property (Parcels $A$ and B) and NMI Property (Lot D), West Concord, Massachusetts, H \& A File No. 06596-42, Cambridge, Massachusetts.

Hodge, H.C., J. V. Stannard, and J. B. Hursh, eds. 1973. "Uranium Plutonium Transplutonic Elements," in Handbook of Experimental Pharmacology XXXVI, Springer Verlag, New York.

ICRP 1994. Human Respiratory Tract Model for Radiological Protection, Publication 66, International Commission on Radiological Protection, Pergamon Press, Oxford; Vol. 24, Nos. 1-3, 1994.

ICRP 1979 and 1980. Limits for Intakes of Radionuclides by Workers, Publication 30, Parts 1 and 2, International Commission on Radiological Protection, Pergamon Press, Oxford; as cited in McGuire 1988.

MacDonald, E.H. 1996. Letter to M. Miller, U.S. Nuclear Regulatory Commission, dated December 31. 
McGuire, S.A. 1988. A Regulatory Analysis on Emergency Preparedness for Fuel Cycle and Other Radioactive Material Licensees, NUREG-1140, Division of Reactor Accident Analysis, Office of Nuclear Regulatory Research, U.S. Nuclear Regulatory Commission, Washington, D.C., January.

Mishima, J., and D. Pinkston 1994. DOE Handbook: Airborne Release Fractions/Rates and Respirable Fractions for Nonreactor Nuclear Facilities, DOE-HDBK-3010-94, U.S. Department of Energy, Washington, D.C.

Mishima, J., M. A. Parkhurst, R. I. Scherpelz, and D. E. Hadlock 1985. Potential Behavior of Depleted Uranium Penetrators Under Shipping and Bulk Storage Accident Conditions, PNL-5415, Pacific Northwest Laboratory, Richland, Washington.

NCRP (National Council on Radiation Protection and Measurements) 1987. Ionizing Radiation Exposure of the Population of the United States, NCRP Report No. 93, Bethesda, Maryland.

NRC (U.S. Nuclear Regulatory Commission) 1996. Joint Report of the Commonwealth of Massachusetts Department of Public Health-Kadiation Control Program and the United States Nuclear Regulatory Commission, Region I, prepared for the Nuclear Metals, Inc., Soil Sampling Discussion Group, King of Prussia, Pennsylvania.

NRC (U. S. Nuclear Regulatory Commission) 1995. Region I Combined Inspection Report of Nuclear Metals, Inc., Concord, Massachusetts, Conducted on November 16 and 17, 1994, Reports No. 040-00672/94-001 and 040-08866/94-001, King of Prussia, Pennsylvania.

ORAU (Oak Ridge Associated Universities) 1983. Environmental Survey of Nuclear Metals. Inc., Concord, Massachusetts, prepared for Division of Fuel Cycle and Material Safety, U. S. Nuclear Regulatory Commission by the Radiological Site Assessment Program. Manpower, Education, Research, and Training Division, Oak Ridge, Tennessee. 


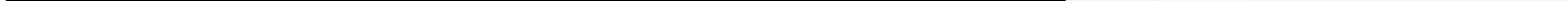




\section{LIST OF AGENCIES AND PERSONS CONSULTED}

Michael Amaral

U.S. Fish and Wildlife Service

New England Field Office

22 Bridge Street

Concord, New Hampshire

Roland Bartal

Acton Planning Department

472 Main Street

Acton, Massachusetts

Dorothy Burke

Sudbury Town Clerk

Town Hall

Sudbury, Massachusetts

Linda Colby

Acton Housing Authority

P. O. Box 681

Acton, Massachusetts

Paul Holtz

Massachusetts Historical Commission

Massachusetts Archive Building

220 Morrissey Boulevard

Boston, Massachusetts

Holly Jewkes

Massachusetts Natural Heritage and

Endangered Species Program

Division of Fisheries and Wildlife

1 Rabbit Hill Road

Westborough, Massachusetts

Bob Larkin

Maynard Housing Authority

195 Main Street

Maynard, Massachusetts 
Edward H. MacDonald

Regional Engineer

Bureau of Waste Prevention

Commonwealth of Massachusetts

Department of Environmental Protection

10 Commerce Way

Woburn, Massachusetts

Jan Manselli

Concord Department of Planning and Land Management

141 Keyes Road

Concord, Massachusetts

Judy Peterson

Maynard Town Clerk

195 Main Street

Maynard, Massachusetts

Department Chief Robinson

Concord Fire Department

Concord, Massachusetts

Don Steele

Division of Air Quality Control

Bureau of Waste Prevention

Commonwealth of Massachusetts

Department of Environmental Protection

37 Shattuck Street

Lawrence, Massachusetts 
APPENDIX A

AGENCY CORRESPONDENCE 


\section{United States Department of the Interior}

FISH AND WILDLIFE SERVICE

New England Field Office

22 Bridge Street, Unit \#1

Concord, New Hampshire 03301-4986

December 6, 1995

Robert L. Miller

Oak Ridge National Laboratory

Bldg $4500 \mathrm{~N}$

P.O. Box 2008

Oak Ridge, TN 37831-6200

Dear Mr. Miller:

This responds to your letter dated November 2, 1995, for information on the presence of federally-listed and proposed, endangered or threatened species in accordance with environmental planning for a license renewal for Nuclear Metals, Inc., in Concord, Massachusetts.

Based on information currently available to us, no federally-listed or proposed, threatened and endangered species under the jurisdiction of the U.S. Fish and Wildlife Service are known to occur in the project area, with the exception of occasional, transient bald eagles (Haliaeetus leucocephalus) or peregrine falcons (Falco peregrinus). However, we suggest that you contact Hanni Dinkeloo of the Massachusetts Natural Heritage and Endangered Species Program, Division of Fisheries and Wildlife, 1 Rabbit Hill Road, Westborough, MA 01581-3337, at 508792-7270, for information on state-listed species, vernal pools, or other rare natural communities that may be present.

Preparation of a Biological Assessment or further consultation with us under Section 7 of the Endangered Species Act is not required. Should project plans change, or additional information on listed or proposed species becomes available, this determination may be reconsidered. 
A list of federally-designated endangered and threatened species in Massachusetts is enclosed for your information. Thank you for your cooperation and please contact Michael Amaral of this office at 603-225-1411 if we can be of further assistance regarding endangered species.

Sincerely yours,

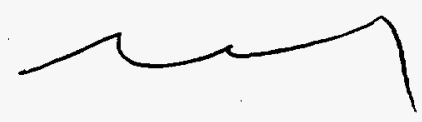

Michael J. Bartlett

Supervisor

New England Field Office

Enclosure 
Common Name

FISHES:

Sturgeon, shortnose*

\section{REPTILES:}

Turtle, green*

Turtle, hawksbill*

Turtle, leatherback*

Turtle, loggerhead*

Turtle, Atlantic ridley*

Turtle, Plymouth redbelly

BIRDS:

Eagle, bald

Falcon, American peregrine

Falcon, Arctic peregrine

Plover, Piping

Roseate Tern

MAMMALS:

Whale, blue*

Whale, finback*

Whale, humpback*

Whale, right*

Whale, sei*

Whale, sperm*

MOLLUSKS:

Mussel, Dwarf wedge

\section{INSECTS: \\ Beetle, Puritan tiger \\ Beetle, northeastern beach tiger \\ Beetle, American burying}

PLANTS:

Small Whorled Pogonia

Gerardia, Sandplain

Bulrush, Northeastern
Scientific Name

Acipenser brevirostrum

E

Chelonia mydas

Eretmochelys imbricata

Dermochelys coriacea

Caretta caretta

Lepidochelys kempii

Chrysemys rubriventris bangsi

Haliaeetus leucocephalus

Falco peregrinus anatum

Falco peregrinus tundrius

Charadrius melodus

Sterna dougallii dougallii

Balaenoptera musculus

Balaenoptera physalus

Megaptera novaeangliae

Eubalaena spp. (all species)

Balaenoptera borealis

Physeter catodon

Alasmidonta heterodon

Cicindela puritana

Cicindela dorsalis dorsalis

$\underline{\text { Nicrophorus americanus }}$

Isotria medeoloides

Agalinus acuta

Scirpus ancistrochaetus $\underline{\text { Status }}$ Distribition

Atlantic coastal waters and rivers (Conn. R.)
T

E

E

$T$

E

E

$T$

E

$\mathrm{T}$

$\mathrm{T}$

E

E

E

E

E

E

E

E

$\mathrm{T}$

$\mathrm{T}$

$\mathrm{E}$

$\mathrm{T}$

E

$\mathrm{E}$ southern New England Oceanic straggler in Southern New England Oceanic summer resident Oceanic summer resident Plymouth \& Dukes Counties
Oceanic straggler in Oceanic summer resident

Nesting in Quabbin Res. and along Conn. R.; entire state-migratory Current nesting: Boston \& Springfield; entire state-migratory Entire state-migratory Atlantic coast Atlantic coast

* Except for sea turtle nesting habitat, principal responsibility for these species is vested with the National Marine Fisheries Service 


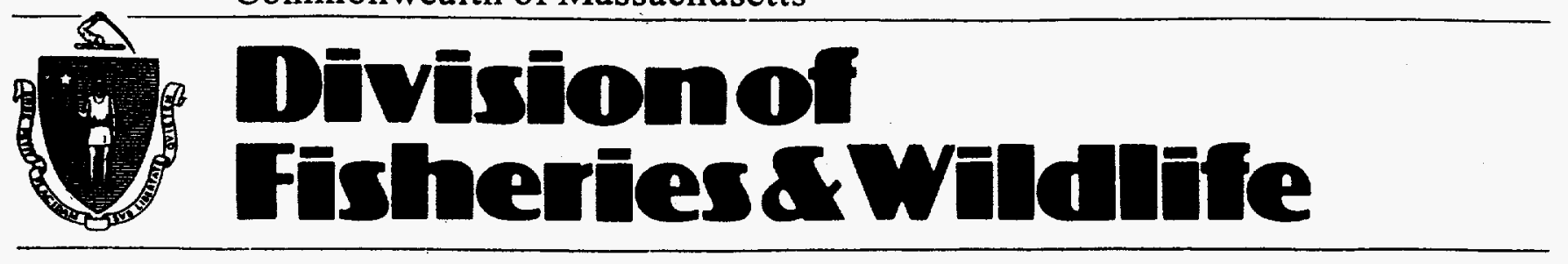

Wayne F. MacCallum, Director

9 January 1996

Robert L. Miller

Lockheed Martin Energy Systems

Oak Ridge National Laboratory

P.O. Box 2008

$4500 \mathrm{~N}, \mathrm{MS} 6200$

Oak Ridge, TN 37831

Re: License Renewal for Nuclear Metals, Inc.

Concord, MA

NHESP File No. 95-1093

Dear Mr. Miller:

Thank you for contacting the Natural Heritage and Endangered Species Program for information regarding state-listed rare species in the vicinity of the site referred to above.

At this time we are not aware of any rare plants or animals or exemplary natural communities in the area of this site.

This review concerns only rare species of plants and animals and ecologically significant natural communities for which the Program maintains site-specific records. This review does not rule out the possibility that more common wildlife or vegetation might be adversely affected if this site is developed, especially if it will modify currently undeveloped areas. Should site plans change, or new rare species information become available, this evaluation may have to be reconsidered.

Please call me if you have any questions.

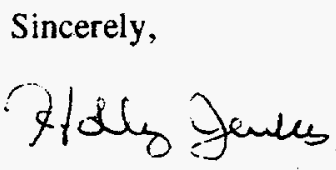

Holly Jewkes

Environmental Review Assistant

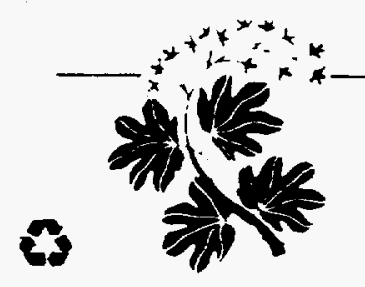

Natural Heritage \& Endangered Species Program

Route 135, Westborough, MA 01581 Tel: (508) 792-7270 × 200 Fax: (508) 792-7275

An Agency of the Department of Fisheries, Wildlife \& Environmental Law Enforcement 
OAK RIDGE NATIONAL LABORATORY

MANAGED BY LOCKHEED MARTIN ENERGY SYSTEMS, INC.

FOR THE U.S. DEPARTMENT OF ENERGY

November 2, 1995
BUILDING 4500N MS-6200

POST OFFICE BOX 2008

OAK RIDGE, TENNESSEE 37831-6200

TELEPHONE: (615) 574-5758

FACSIMILE: (615) 574-5788

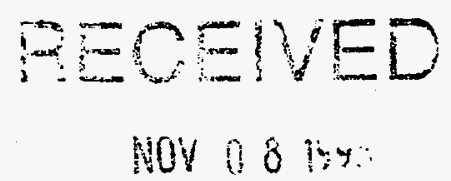

MASS. FIST. COMM.

Mr. Paul Holtz

Massachusetts Historical Commission

Massachusetts Archive Building

220 Morrissey Blvd.

Boston, Massachusetts 02125

Dear Mr. Holtz:

Section 106 Consultation for License Renewal for Nuclear Metals, Inc., Concord, Massachusetts

The Nuclear Regulatory Commission (NRC) has responsibility for licensing industries which handle radioactive materials. The NRC has received an application for license renewal from Nuclear Metals, Inc. (NMI) in Concord, Massachusetts, to permit the continuation of ongoing operations there for at least the next five years. Oak Ridge National Laboratory is assisting the NRC in preparing an Environmental Assessment (EA) on the proposed license renewal in accordance with the National Environmental Policy Act (NEPA) and NRC's regulations implementing NEPA. In order to coordinate NEPA implementation with that required by Section 106 of the National Historic Preservation Act of 1966, this letter identifies the impact of the proposed action on any significant archaeological, cultural, and/or historical areas that are located at the NMI site.

While the renewal application is being considered, NMI is currently allowed to operate under two NRC licenses which are beyond their original expiration dates. NRC license renewal is needed to permit the continuation of NMI operations involving radioactive materials. Products manufactured at the plant have important military and medical applications, with about half of the U. S. demand for such products being met by the NMI facilities. If NMI ceases these operations, a shortage of these products could occur which might adversely affect national security and health care.

NMI is located approximately $31 \mathrm{~km}$ (19 miles) northwest of Boston in the town of Concord (Figures 1 and 2). The facility lies on approximately 18.5 ha (45.7 acres) of land, with the Assabet River located about $50 \mathrm{~m}$ (165 ft) north of the site boundary (Figure 3 ). NMI began operations in 1942 as part of metallurgical research and development activities for the Manhattan Project at the Massachusetts Institute of Technology (MIT). The research and development activities were converted to private ownership in 1954 and moved from the MIT campus to its present location in 1958. The NMI facilities originally consisted of Buildings A, B, and C. Buildings D and E were added in 1978 and 1983, respectively. 
Mr. Paul Holtz

November 2, 1995

Page 2

Activities associated with the proposed license renewal would be located in existing facilities which cover about 8 ha (19 acres) of the site. The facilities and immediately adjacent area have been thoroughly disturbed by previous construction. Therefore, there is no possibility that any National Register-eligible historic properties exist there. Additionally, no modification to existing facilities, new construction, or earth-disturbing activities would occur with the license renewal. The remaining area at the site [approximately 11 ha (26 acres)] is undeveloped. The proposed license renewal would have no impact on any property included in, or eligible for inclusion in, the National Register of Historic Places.

Please let me know if you concur with this assessment. If you have any questions, please feel free to call me at (423) 576-0751. Thank you for your help.

Sincerely,

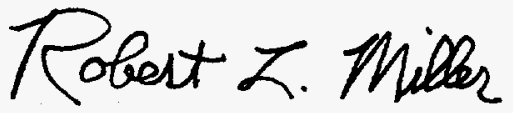

Robert L. Miller

Project Leader

Enclosures: Figure 1

Figure 2

Figure 3

cc: D. Lombardi, ORNL

L. McCold, ORNL

M. Miller, NRC Region I

R. Reed, ORNL

P. Santiago, NRC HQ

D. Tiktinsky, NRC HQ

I. Treitler, ORNL

F. Vumbaco, NMI

After review of MHC files and the material you submitted, it has been determined that this projext is unlikely to affect significant

historic or archacological resources.

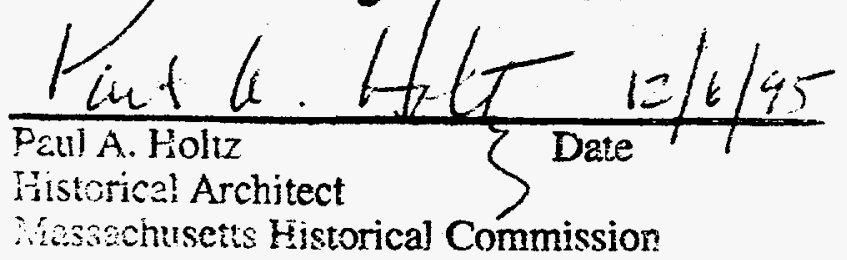




\section{APPENDIX B}

ASSUMPTIONS, CONSTRANTS, AND LIMITATIONS

IN THE ANALYSIS OF ACCIDENTAL ATMOSPHERIC RELEASES OF URANIUM 


\section{APPENDIX B}

\section{ASSUMPTIONS, CONSTRAINTS, AND LIMITATIONS IN THE ANALYSIS OF ACCIDENTAL ATMOSPHERIC RELEASES OF URANIUM}

The analyses in this environmental assessment (EA) include consideration of accidents that could release radioactive materials (i.e., uranium) from the facilities of Nuclear Metals, Inc. (NMI), in Concord, Massachusetts. The equations used in the accident analyses are contained in Section 3.1.2 of this EA. The equations were taken from McGuire (1988) and Mishima and Pinkston (1994) and were adapted for the presentation and format of this EA. The principal assumptions, constraints, and limitations of these equations (and of the numerical inputs to these equations) are presented in this appendix.

\section{B.1 INTRODUCTION}

In 1987, the Nuclear Regulatory Commission (NRC) conducted a regulatory analysis (in NUREG-1140; see McGuire 1988) of its fuel cycle and other radioactive material licensees to identify the classes of licensees that could have accidents with the potential to result in radiation doses to the public exceeding protective action guides established by the U.S. Environmental Protection Agency (EPA). In that regulatory analysis, the plausibility of exceeding EPA's protective action guides was considered from two points of view: (1) the accident history of fuel cycle and byproduct material licensees, and (2) theoretical calculations of the releases and offsite doses of credible accidents.

The regulatory analysis in NUREG-1140 (McGuire 1988) evaluated many plausible accident scenarios for various types of licensed facilities. The most significant accidents were determined to be $\mathrm{UF}_{6}$ releases, fires, and criticality accidents. Aside from the special cases of $\mathrm{UF}_{6}$ releases and criticalities, the fraction of radioactive material released in fires was considered to be larger than that released in other types of accidents. The regulatory analysis concluded that for facilities such as those at NMI, accidental releases from fires should be used to determine whether protective action guides would be exceeded in the event of an accident. The accident analysis for this EA therefore focuses on fires at the NMI facility. 
In NUREG-1140, doses from airborne releases were calculated by (1) assuming release fractions for the radioactive materials involved in the fire, (2) employing an atmospheric dispersion model, and (3) calculating doses to a downwind receptor from three pathways: inhalation, cloudshine (from radioactive particulate matter suspended in the air), and groundshine (from particulate matter deposited on the ground). For uranium, NUREG-1140 found that the highest doses come from the inhalation pathway, and doses from the other pathways could be reasonably ignored.

\section{B.2 CONSERVATISMS IN THE CALCULATIONS IN NUREG-1140}

The regulatory analysis in NUREG-1140 contains a discussion of the conservatism (or pessimism) in the computational methodology. It states:

"Doses to people near a plant experiencing a severe accident are likely to be far below the doses in this analysis, probably by an order of magnitude or more, except in very unusual circumstances. The accident history of such facilities in the U.S. is that there is no known case of a member of the public receiving even as much as $1 \%$ of the doses calculated in this analysis as the result of an accidental airborne release ...."

The factors contributing to this degree of conservatism are enumerated in NUREG-1140 and are repeated below:

- Licensed quantities of radioactive materials are used in the calculations. In actuality, most licensees possess much less material at any particular time than they are legally authorized to possess. Also, in many cases, the possessed material is located at different locations and would not be subject to release during a particular accident.

- Worst-case release fractions. The release fractions due to fires were derived from experiments designed to maximize releases. Such experiments include unrestricted exposure to a fire involving source materials in fine powder form or in long, thin bars 
with high surface-to-volume ratios. Having the entire licensed inventory unenclosed and in close proximity to a large quantity of combustible material would be most unusual.

- No credit for engineered safeguards or response effort. No credit is given for design features or operating procedures that could reduce the likelihood of an accidental release or reduce the quantity of radioactive material released. No credit is given for sprinkler systems designed to stop fires. No credit is given for ventilation or filtration systems during a fire. No credit is given for fire fighting efforts to stop the fire before it reaches the radioactive materials. Little or no credit is given for holding up the release of material by means of deposition or plateout.

- The exposed individual makes no response. The dose is calculated for an individual standing directly downwind on the plume centerline. In the case of a fire, such a person would be standing in dense smoke or irritating fumes. Realistically, people can be expected to move from such positions to avoid smoke inhalation.

- No plume rise for releases from fires. No credit is given for plume rise due to buoyancy of the heated material released in a fire. The plume is assumed to be released at and remain at ground level. This presents the highest possible downwind concentrations to exposed individuals.

- Conservative dosimetry. The radioactive material is assumed to have the solubility which would result in the highest dose per curie inhaled. Particulate matter is generally assumed to have a size of $1 \mu \mathrm{m}$, making it highly respirable and transportable to deep within the lungs where it would be difficult to remove.

- Adverse meteorology. Downwind concentrations of radioactive materials were calculated for "worst case" conditions of atmospheric stability class $F$ with a $1 \mathrm{~m} / \mathrm{s}(2 \mathrm{mph})$ wind speed. These conditions result in minimal dilution and high doses along the plume centerline, but also result in very narrow plumes. It is probable that the actual meteorological conditions would cause enhanced atmospheric dispersion and would result in lower doses. 
- The affected individual is located in an open field. A rural open-field site is assumed for the location of the affected individual. Greater atmospheric dispersion and thus lower doses would occur at an urban or suburban site because buildings, trees, or other obstacles in the plume path would broaden the plume and would encourage mixing and atmospheric dilution.

- There may be no one located on the plume centerline. The doses are calculated for an individual located at a single point, and they fall off rapidly as one moves away from that point. Even with no protective actions, the highest dose anyone would receive is likely to be well below the calculated dose.

NUREG-1140 also enumerates certain assumptions in the dose calculation that may not be conservative in some instances. These factors are repeated below:

- Adult doses. Doses are calculated for adults rather than children because dose conversion factors for children using modern dosimeter models are generally not available.

- Breathing rates. The breathing rate used in the dose calculations $\left(2.66 \times 10^{-4} \mathrm{~m}^{3} / \mathrm{s}\right.$ or $8,390 \mathrm{~m}^{3} / \mathrm{y}$ ) represents an average breathing rate. Breathing rates for above-average activity would be higher and would result in larger quantities of material being inhaled and thus higher doses.

\section{B.3 ADDITIONAL ASSUMPTIONS IN THE CALCULATIONS FOR THIS EA}

Several additional assumptions were derived from Mishima and Pinkston (1994) and from visual inspection of the NMI facilities. These assumptions were incorporated into the NMI-specific accident and exposure calculations contained in Section 3.1.2 of this EA. These assumptions include:

- fire is the sole accident initiator of concern; 
- a fire would be limited to a single building by installed fire walls;

- the release pathway is through the skylights in the building, and would bypass the installed ventilation exhaust and filtration systems;

- a sufficient quantity of combustible material is present to sustain a lengthy, hot fire;

- the fire involves the entire process-specific inventory of depleted uranium within a single building;

- the fire involves the entire inventory of natural uranium at NMI;

- only the uranium oxidized by the fire can become airborne;

- not all of the oxidized uranium would become airborne;

- not all of the airborne material is respirable (i.e., less than $10 \mu \mathrm{m}$ in aerodynamic diameter);

- Gaussian dispersion of the radioactive material through the atmosphere is assumed;

- inhalation of radioactive material is the only significant exposure pathway; cloudshine (from suspended particles) and groundshine (from deposition) are not included;

- the maximally exposed individual is assumed to be:

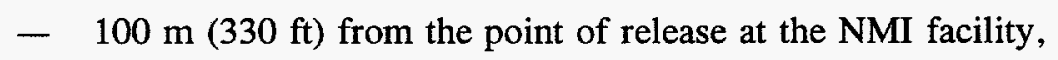

- in an open field (i.e., not inside a building),

- located on the plume centerline, and

- breathing normally; and

- F stability with a wind speed of $1 \mathrm{~m} / \mathrm{s}(2 \mathrm{mph})$ is assumed to represent "worst case" meteorological conditions. 


\section{B.4 CONCLUSIONS}

The collective implication of the above assumptions is that the quantities of inhaled uranium calculated in Section 3.1.2 of this EA are likely to be overestimates, possibly by as much as one or two orders of magnitude. Doses calculated from these inhaled quantities are also likely to be overestimates. For these reasons, the calculated values should be viewed as upper bound estimates only. 


\begin{tabular}{|c|c|}
\hline $\begin{array}{l}\text { NRC FORM } 395 \\
(2-89) \\
\text { NRCM 1102. } \\
3201,3202 \\
\text {. }\end{array}$ & $\begin{array}{l}\text { U.S. MUCL } \\
\text { BIBLIOGRAPHIC DATA SHEET } \\
\text { (Seo instructions on the reverse) }\end{array}$ \\
\hline
\end{tabular}

\section{TITLE AND SUBTITLE}

Environmental Assessment

Proposed License Renewal of Nuclear Metals, Inc.

Concord, Massachusetts

(See instructions on the reverse)

5. AUTHOR(S)
Miller, R. L., Easterly, C. E., Lombardi, D. A., Treitler, I. E., Winbow, R. T., Zimmerman, G. P.

1. REPORT NUMBER

(Assigned by NRC, Add Vol, supp., Rev., and Addendum Numbers, tf any.)

\section{NUREG/CR-6528}

3. DATE REPORT PUBLISHED

\begin{tabular}{l|l} 
MONTH & YEAR
\end{tabular}

February 1997

4. FIN OR GRANT NUMBER $J 5084$

6. TYPE OF REPORT

Technical

7. PERIOD COVERED (nclusive Dalos)

8. PERFORIMNG ORGANIZATION - NAME AND ADDRESS (IF NRC, provide Division, Ofico or Region, U.S. Nuclear Regulatory Commission, and meiling eddress; if contrector, provido name and mailing address.)

Oak Ridge National Laboratory

Oak Ridge, TN 37831

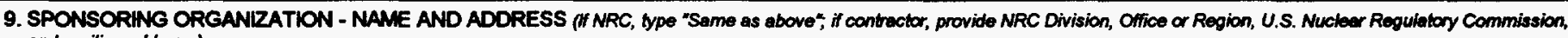
and mailing address.)

Division of Industrial and Medical Nuclear Safety

Office of Nuclear Material Safety and Safeguards

U.S. Nuclear Regulatory Commission

Washington, DC 20555-0001

10. SUPPLEMENTARY NOTES

Docket Numbers 040-00672 and 040-08866

11. ABSTRACT (200 words or lass)

This Environmental Assessment was prepared to evaluate environmental issues associated with the renewal of NRC Licensee Nos. SMB-179 and SUB-1452 for facilities operated by Nuclear Metals, Inc. (NMI) in Concord Massachusetts. License renewal is needed to permit the continuation of NMI operations involving depleted and natural uranium.

12. KEY WORDSIDESCRIPTORS (List words or phrases that will assist reseerchers in loceting the report.)
13. AVALABILITY STATEMENT

Environmental Assessment

Depleted Uranium

Natural Uranium

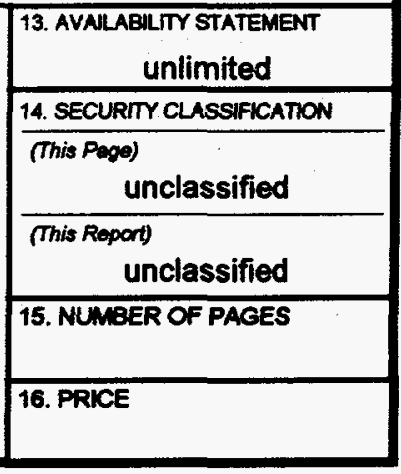

